\title{
Study of the anti-allergic and anti- inflammatory activity of Brachychiton rupestris and Brachychiton discolor leaves (Malvaceae) using in vitro models
}

Amany A. Thabet ${ }^{1 \dagger}$, Fadia S. Youssef ${ }^{1 \dagger}$, Michal Korinek ${ }^{2,3,4,5}$, Fang-Rong Chang ${ }^{2,6}$, Yang-Chang Wu ${ }^{2,7,8}$, Bing-Hung Chen ${ }^{3,8,9}$, Mohamed El-Shazly ${ }^{1,10^{*}}$, Abdel Nasser B. Singab ${ }^{1^{*}}$ and Tsong-Long Hwang ${ }^{4,5,11,12,13^{*}}$

\begin{abstract}
Background: Brachychiton rupestris and Brachychiton discolor (Malvaceae) are ornamental trees native to Australia. Some members of Brachychiton and its highly related genus, Sterculia, are employed in traditional medicine for itching, dermatitis and other skin diseases. However, scientific studies on these two genera are scarce. Aiming to reveal the scientific basis of the folk medicinal use of these plants, the cytotoxicity, anti-inflammatory and anti-allergic activities of Brachychiton rupestris and Brachychiton discolor leaves extracts and fractions were evaluated. Also, phytochemical investigation of $B$. rupestris was performed to identify the compounds exerting the biological effect.

Methods: Extracts as well as fractions of Brachychiton rupestris and Brachychiton discolor were tested for their cytotoxicity versus hepatoma HepG2, lung A549, and breast MDA-MB-231 cancer cell lines. Assessment of the antiallergic activity was done using degranulation assay in RBL-2H3 mast cells. Anti-inflammatory effect was tested by measuring the suppression of superoxide anion production as well as elastase release in fMLF/CB-induced human neutrophils. Phytochemical investigation of the $n$-hexane, dichloromethane and ethyl acetate fractions of $B$. rupestris was done using different chromatographic and spectroscopic techniques.

Results: The tested samples showed no cytotoxicity towards the tested cell lines. The nonpolar fractions of both $B$. rupestris and $B$. discolor showed potent anti-allergic potency by inhibiting the release of $\beta$-hexosaminidase. The dichloromethane fraction of both species exhibited the highest anti-inflammatory activity by suppressing superoxide anion generation and elastase release with $\mathrm{IC}_{50}$ values of 2.99 and $1.98 \mu \mathrm{g} / \mathrm{mL}$, respectively for $B$. rupestris, and 0.78 and $1.57 \mu \mathrm{g} / \mathrm{mL}$, respectively for $B$. discolor. Phytochemical investigation of various fractions of $B$. rupestris resulted in the isolation of $\beta$-amyrin acetate (1), $\beta$-sitosterol (2) and stigmasterol (3) from the $n$-hexane fraction. Scopoletin (4) and $\beta$ sitosterol-3-O- $\beta$-D-glucoside (5) were obtained from the dichloromethane fraction. Dihydrodehydrodiconiferyl alcohol 4-O- $\beta$-D-glucoside (6) and dihydrodehydrodiconiferyl alcohol 9-O- $\beta$-D-glucoside (7) were separated from the ethyl acetate fraction. Scopoletin (4) showed anti-allergic and anti-inflammatory activity.
\end{abstract}

Conclusions: It was concluded that the nonpolar fractions of both Brachychiton species exhibited anti-allergic and anti-inflammatory activities.

Keywords: Anti-allergic, Anti-inflammatory, Brachychiton discolor, Brachychiton rupestris, Cytotoxicity, Phytochemistry

\footnotetext{
* Correspondence: mohamed.elshazly@pharma.asu.edu.eg;

dean@pharma.asu.edu.eg; ht|@mail.cgu.edu.tw

${ }^{+}$Amany A. Thabet and Fadia S. Youssef contributed equally to this work.

'Department of Pharmacognosy, Faculty of Pharmacy, Ain Shams University,

African Union Organization Street, Abbassia, Cairo 11566, Egypt

${ }^{4}$ Graduate Institute of Natural Products, College of Medicine, Chang Gung

University, Taoyuan 33302, Taiwan

Full list of author information is available at the end of the article
}

(c) The Author(s). 2018 Open Access This article is distributed under the terms of the Creative Commons Attribution 4.0 International License (http://creativecommons.org/licenses/by/4.0/), which permits unrestricted use, distribution, and reproduction in any medium, provided you give appropriate credit to the original author(s) and the source, provide a link to the Creative Commons license, and indicate if changes were made. The Creative Commons Public Domain Dedication waiver (http://creativecommons.org/publicdomain/zero/1.0/) applies to the data made available in this article, unless otherwise stated. 


\section{Background}

Allergy is one of the most popular diseases worldwide and its great prevalence makes allergic disorder a growing global concern [1]. Allergic reaction can be defined as the development of signs and symptoms of hypersensitivity reactions upon exposure to certain allergenic substances resulting in massive production of allergen-specific $\mathrm{IgE}$ and allergen-specific T-cell populations [2]. Allergic reaction can be a life-threatening condition especially in anaphylaxis and severe asthma or it can be a chronic condition that interferes with the quality of life such as in eczema and allergic rhinitis [3].

Inflammation is another common disorder which is an innate immune response from the host defense mechanism. It consists of a series of complex biological processes aiming to combat infection and tissue injury. These processes lead to accumulation of plasma and blood cells in the tissue in addition to the release of inflammatory mediators aiming to reestablish tissue structures and function $[4,5]$. Untreated inflammation can lead to a chronic condition which is characterized as a very long-term inflammation affecting the remodeling of tissue for many weeks and even years. It is considered as a main cause in the development of a various life threatening disorders, such as neurodegenerative diseases and cancers [4].

Non-steroidal anti-inflammatory drugs (NSAIDs) constitute the commonly adopted classes for the alleviation of inflammation and related conditions. Meanwhile, their intolerable side effects represented by gastrointestinal ulcers, and perforation with concomitant bleeding are the main obstacles facing their therapeutic usage [6]. On the contrary, nature continues to serve as a rich and appealing source of novel, safer, and cheaper bioactive molecules in comparison to many synthetic drugs. A plethora of plant extracts, as well as isolated compounds, possess notable anti-allergic and anti-inflammatory activities, as previously reported $[5,7-11]$.

Malvaceae, the mallows, is a family that comprises more than 200 genera and 2300 species. A great diversity of phytoconstituents such as triterpenes, flavonoids, coumarins, as well as alkaloids was previously reported in the members of this family $[12,13]$. Brachychiton (Malvaceae) is a small genus native to Australia comprising of 30 species [14, 15]. Recently, Brachychiton has been considered as a separate genus from Sterculia as proved by the detailed investigation of its follicles, seed coats and embryo [14]. Members of the Brachychiton genus were used as food by Australian Aborigines and some are used as ornamental trees or shrubs $[16,17]$. Different members of the genus possess several interesting biological effects such as antioxidant, antibacterial, anti-hyperglycemic, hepatoprotective and anti-schistosomal activities [18-21]. Phytochemical studies of various members of Brachychiton sp. resulted in the identification of various classes of compounds such as flavonoids, coumarins, triterpenes, sterols, and alkaloids [22-24]. Brachychiton rupestris is commonly known as "Queensland bottle tree" because it is native to Queensland and has a bottle shaped trunk. B. discolor (synonym $B$. luridus) is commonly called the lacebark tree [25-27]. The mucilage and ethyl acetate fraction of $B$. rupestris leaves were previously investigated for their in vivo anti-hyperglycemic effect and the phytochemical investigation of this species led to the isolation and identification of flavonoid aglycones and glycosides from the leaves [20, 28]. However, no complete phytochemical study was done on this species. Regarding $B$. discolor, two complete phytochemical studies were reported on this species where many classes of compounds were reported from the leaves, seeds and roots including triterpenes, flavonoids, phenolic acids, coumarins and alkaloids [23, 24].

Tracing current literature, nothing was found regarding the anti-allergic and anti-inflammatory effects of $B$. rupestris. However, different studies were carried out confirming the anti-allergic and anti-inflammatory activities of several triterpenes such as $\beta$-amyrin, oleanolic acid and lupeol [29-33] which were also isolated from $B$. discolor [23, 24]. Another species (B. populneus) was reported to be effective in relieving pain and skin diseases in folk medicine [34]. Furthermore, many members of the related genus, Sterculia, are popular in folk medicine for alleviating itching, dermatitis, boils, inflammations and other skin diseases [35-40]. Herein, we investigated the anti-allergic and anti-inflammatory activities of the methanol extracts and fractions of both $B$. rupestris and $B$. discolor leaves. The cytotoxic effect of $B$. rupestris and $B$. discolor leaves extracts and fractions was also evaluated to ascertain their safety. Additionally, the isolation and structural elucidation of the major constituents from the bioactive fractions of $B$. rupestris was achieved within this work.

\section{Methods \\ Plant materials}

The leaves of B. rupestris (T.Mitch.ex Lindl) K.Schum and $B$. discolor F.Muell were obtained from El-Orman Botanical Garden, Giza, Egypt, in summer 2014. The plants were generously authenticated by Prof. Dr. Mohamed El-Gibaly, Department of Botany, National Research Center (NRC), Giza, Egypt. Voucher specimens (PHG-P-BR-248 and PHG-P-BL-249) for B. rupestris and $B$. discolor (B. luridus), respectively were kept at the Pharmacognosy Department, Faculty of Pharmacy, Ain Shams University.

\section{Extraction and fractionation}

Total amount of $3.05 \mathrm{~kg}$ of B. rupestris air-dried leave were crushed, macerated in $29 \mathrm{~L}$ of distilled methanol 
for three times and filtered. Subsequently, the obtained filtrate was evaporated in vacuo at low temperature $\left(45^{\circ}\right.$ C) till dryness and then subjected to lyophilization to give $333.56 \mathrm{~g}$ of the total methanol extract. A portion of the extract $(300 \mathrm{~g})$ was successively partitioned with $n$-hexane $(37.9 \mathrm{~L})$, dichloromethane $(4.8 \mathrm{~L})$ and ethyl acetate (5.2 L) to give 54.35, 8.54 and $5.91 \mathrm{~g}$, respectively along with the remaining hydromethanolic fraction estimated as $191.5 \mathrm{~g}$.

Similarly, for $B$. discolor, the crushed air-dried leaves $600 \mathrm{~g}$ were macerated in distilled methanol $(6 \mathrm{~L} \times 3)$, filtered, and evaporated at $45{ }^{\circ} \mathrm{C}$ under reduced pressure till dryness to yield $36 \mathrm{~g}$ of the total methanol extract. Then, $11 \mathrm{~g}$ of the total extract were fractionated using $430 \mathrm{~mL}$ of $n$-hexane, $300 \mathrm{~mL}$ of dichloromethane and $300 \mathrm{~mL}$ of ethyl acetate successively to give $1.3,1.2$, and $0.9 \mathrm{~g}$ of the dried residues, respectively.

\section{Biological investigations \\ In vitro assessment of the cytotoxic activity}

Cell culture The cytotoxicity of B. rupestris and B. discolor total extracts as well as their obtained fractions was examined on A549 (adenocarcinoma human alveolar basal epithelial cells), HepG2 (human liver cancer cell line) and MDA-MB-231 (invasive ductal carcinoma) cells. Cells were preserved in Dulbecco's modified Eagle's medium-high glucose powder (DMEM) containing 10\% heat-inactivated fetal bovine serum (FBS), $1 \mathrm{mM}$ sodium pyruvate, $100 \mu \mathrm{g} / \mathrm{mL}$ streptomycin, $100 \mathrm{U} / \mathrm{mL}$ penicillin, and $2 \mathrm{mM}$ L-glutamine. Cells were cultured in culture dishes (Cellstar) that were kept in a humidified chamber supplied with $5 \%(v / v) \mathrm{CO}_{2}$ at $37^{\circ} \mathrm{C}$. Then the cells were maintained as a monolayer culture adopting serial subculturing. Cells growing in the logarithmic phase were employed in all experiments [41].

Cytotoxicity assay MTT (methylthiazoltetrazolium) assay was employed to evaluate the cytotoxic activity of the tested samples against human cancer cells [42, 43]. Trypsinized cell suspensions were freshly prepared and then planted in a 96-well culture plate followed by overnight incubation. Tested samples were prepared in dimethyl sulfoxide (DMSO) to form stock solutions of $1 \mathrm{mg} / \mathrm{mL}$. Cells were treated with the tested samples using different concentrations $(2.5-20 \mu \mathrm{g} / \mathrm{mL})$ then incubated for $72 \mathrm{~h}$ at $37{ }^{\circ} \mathrm{C}$ under $5 \% \mathrm{CO}_{2}$. After the incubation, and removal of the cells medium, $100 \mu \mathrm{L}$ of MTT solution was added to each well followed by incubation of the cells for $1 \mathrm{~h}$. The formed formazan crystals were dissolved in DMSO after the removal of the medium to measure absorbance at $550 \mathrm{~nm}$. The percentage of cell viability was calculated by the following formula:
$\%$ cell viability $=\frac{\text { O.D of treated cells-O.D of culture medium }}{\text { O.D of untreated cells-O.D of culture medium }} \times 100$

Where O.D = optical density

Cytotoxicity was expressed as \% cell inhibition. Doxorubicin was used as the positive control.

\section{In vitro assessment of the anti-allergic activity}

Chemicals and reagents DMEM, dexamethasone, $p$-nitrophenyl- $N$-acetyl-D-glucosaminide ( $p$-NAG), MTT (3-(4,5-dimethylthiazol-2-yl)-2,5-diphenyltetrazolium bromide), penicillin and streptomycin, calcium ionophore A23187, mouse anti-DNP (dinitrophenyl) IgE antibody, and DMSO were purchased from Sigma-Aldrich (St. Louis, MO, USA). Moreover, FBS was obtained from Hyclone (Logan, UT, USA). Dinitrophenyl-conjugated bovine serum albumin (DNP-BSA) was purchased from Merck (Kenilworth, NJ, USA). Additional chemicals as well as reagents were purchased at the highest possible purity.

Cell culture The mucosal mast cell-derived rat basophilic leukemia (RBL-2H3) cell line was obtained from the American Type Culture Collection. Cells were grown in DMEM medium accompanied with $10 \% \mathrm{FBS}$ in addition to $100 \mathrm{U} / \mathrm{mL}$ penicillin plus $100 \mu \mathrm{g} / \mathrm{mL}$ streptomycin. Cells were cultured in $10 \mathrm{~cm}$ cell culture dishes (Cellstar) at $37{ }^{\circ} \mathrm{C}$ with $5 \% \mathrm{CO}_{2}$ in air.

Cell viability assay MTT assay was used to assess the toxic effects of samples on RBL-2H3 cells [44] and was done as previously mentioned [42, 43]. All experiments were done in triplicates. DMSO served as the negative control not affecting the growth of RBL-2H3 cells. Triton X-100 (0.5\% solution) was employed as the positive control resulting in the death of all cells in a well.

Degranulation $\beta$-hexosaminidase assay induced by A23187 A23187-induced degranulation in RBL-2H3 cells was evaluated by a $\beta$-hexosaminidase activity assay as previously reported employing certain modifications $[45,46]$. RBL-2H3 cells were seeded into 96-wells plate using a density of $2 \times 10^{4}$ cells/well and were incubated at $37{ }^{\circ} \mathrm{C}$ for $5 \mathrm{~h}$ in $5 \% \mathrm{CO}_{2}$. Cells were washed with PBS (phosphate buffered saline) and then various concentrations of samples or medium (untreated control) were added to each well $(100 \mu \mathrm{L})$, and the treated cells were incubated at $37{ }^{\circ} \mathrm{C}$ in $5 \% \mathrm{CO}_{2}$ for $20 \mathrm{~h}$. The cells were stimulated by calcium ionophore A23187 $(1 \mu \mathrm{M})$ diluted in Tyrode's buffer $(135 \mathrm{mM} \mathrm{NaCl}, 1.8 \mathrm{mM} \mathrm{CaCl} 2,5 \mathrm{mM} \mathrm{KCl}, 1.0 \mathrm{mM}$ $\mathrm{MgCl}_{2}, 5.6 \mathrm{mM}$ glucose, $20 \mathrm{mM}$ HEPES at $\mathrm{pH}$ 7.4), and kept at $37{ }^{\circ} \mathrm{C}$ in $5 \% \mathrm{CO}_{2}$ for $1 \mathrm{~h}$. For the total amount of $\beta$-hexosaminidase release, the unstimulated cells were lysed using $0.5 \%$ Triton X-100. Untreated unstimulated 
cells represented spontaneous $\beta$-hexosaminidase release. The control wells were represented by the stimulated untreated cells. The cells supernatants $(50 \mu \mathrm{L})$ were incubated with equal volume of $1 \mu \mathrm{M}$ of p-NAG $(50 \mu \mathrm{L})$, a substrate for $\beta$-hexosaminidase, prepared in $0.05 \mathrm{M}$ citrate buffer ( $\mathrm{pH} 4.5)$ for $1 \mathrm{~h}$ at $37^{\circ} \mathrm{C}$. The reaction was stopped by $100 \mu \mathrm{L}$ of stop buffer $\left(0.1 \mathrm{M} \mathrm{Na}_{2} / \mathrm{NaHCO}_{3}, \mathrm{pH} 10.0\right)$. Microplate reader was used to measure the absorbance at $405 \mathrm{~nm}$. The inhibition percentage of $\beta$-hexosaminidase release from RBL-2H3 cells was calculated using the following equation:

$$
\text { Inhibition }(\%)=\left[1-\frac{(\text { ODsample-ODspontaneous })}{(\text { ODcontrol-ODspontaneous })}\right] \times 100
$$

Dexamethasone (10 nM) was employed as the positive control.

Degranulation $\beta$-hexosaminidase assay induced by IgE $\beta$-Hexosaminidase release from the activated RBL-2H3 cells was measured as previously reported [45, 47], with some modifications. The inhibition percentage of antigen-induced $\beta$-hexosaminidase release from RBL-2H3 cells was assessed in a similar way as described above in the degranulation A23187-induced $\beta$-hexosaminidase assay, except of the stimulation process. The cells were sensitized with anti-DNP IgE $(0.1 \mu \mathrm{g} / \mathrm{mL})$ for at least $2 \mathrm{~h}$ and then washed with pre-warmed Tyrode's buffer, followed by stimulation by antigen DNP-BSA $(100 \mathrm{ng} / \mathrm{mL})$. Dexamethasone $(10 \mathrm{nM})$ was employed as the positive control.

\section{In vitro assessment of the anti-inflammatory activity}

Preparation of human neutrophils Blood was withdrawn from 20 to 35 years old healthy human donors adopting a protocol approved by the institutional review board at Chang Gung Memorial Hospital. Isolation of neutrophils was done employing a standard method which was previously reported [48].

\section{Measurement of superoxide generation}

Ferricytochrome $c(0.5 \mathrm{mg} / \mathrm{mL})$ and $\mathrm{Ca}^{2}(1 \mathrm{mM})$ were incubated with neutrophils at $37^{\circ} \mathrm{C}$ for $2 \mathrm{~min}$, followed by the treatment with the tested samples for $5 \mathrm{~min}$. Cells activation was done using formyl-methionyl-leucyl-phe nylalanine (fMLF, $100 \mathrm{nM}$ )/cytochalasin B (CB, $1 \mu \mathrm{g}$ / $\mathrm{mL}$ ) for $10 \mathrm{~min}$. The absorbance was detected at $550 \mathrm{~nm}$ in a double-beam spectrophotometer Hitachi U-3010. Superoxide inhibition was determined by lowering ferricytochrome $c$ as reported previously $[48,49]$. The differences in absorbance between the measurements in the presence of superoxide $(100 \mathrm{U} / \mathrm{mL})$ and its absence divided by the extinction coefficient for the reduction of ferricytochrome $c(\varepsilon=21.1 / \mathrm{mM} / 10 \mathrm{~mm})$ were used as the basis for calculations. Genistein was adopted as the positive control [50,51].

\section{Measurement of elastase release}

The release of elastase was determined by assessing the degranulation of azurophilic granules [48, 49]. An elastase substrate MeO-Suc-Ala-Ala-Pro-Val- $p$-nitroanilide $(100 \mu \mathrm{M})$ was equilibrated with neutrophils at $37^{\circ} \mathrm{C}$ for $2 \mathrm{~min}$, followed by incubation with drugs for $5 \mathrm{~min}$. Activation of the cells was done using $100 \mathrm{nM}$ fMLF and $0.5 \mu \mathrm{g} / \mathrm{mL} \mathrm{CB}$, and then the variations in absorbance were detected at $405 \mathrm{~nm}$. The results are shown as the percentage of the initial rate of elastase release in the fMLF/CB-activated, drug-free control system. Genistein was employed as the positive control [50,51].

\section{Statistical analysis}

Results are represented as mean \pm SD value of at least three independent measurements unless otherwise specified. The $50 \%$ inhibitory concentration $\left(\mathrm{IC}_{50}\right)$ was determined using the dose-response curve which was constructed by plotting the percentage of inhibition versus concentrations (linear function, Microsoft Office). Statistical analysis was done using one-way analysis of variance (ANOVA) followed by Dunnet's test (GraphPad Prism 6.0, GraphPad Software, Sand Diego, CA, USA, anti-allergic assay) or Student's $t$-test (Sigma Plot, Systat software, Systat Software Inc., San Jose, CA, USA, anti-inflammatory assay). Values which show ${ }^{*} p<0.05$, $* p<0.001$ are statistically significant.

\section{Phytochemical investigations}

\section{General experimental procedures}

${ }^{1} \mathrm{H}$ and ${ }^{13} \mathrm{C}$ (APT) NMR analyses were done using a Bruker Ascend 400/R spectrometer (Burker Avance III, Fallanden Switzerland) at the Center for Drug Discovery, Research and Development, Faculty of Pharmacy, Ain Shams University using 400 and $100 \mathrm{MHz}$ the operating frequencies. Chemical shifts were reported in $\delta \mathrm{ppm}$ and were related to that of the solvents. Dissolution of the tested samples was done using various deuterated solvents (Sigma Aldrich, Germany) in $3 \mathrm{~mm}$ NMR tubes (Bruker). Spectra were recorded at $25{ }^{\circ} \mathrm{C} ; \delta$ ppm relative to tetramethylsilane $\left(\mathrm{Me}_{4} \mathrm{Si}\right)$ as the internal standard. Two-dimensional (2D) NMR experiments $\left({ }^{1} \mathrm{H},{ }^{1} \mathrm{H}-{ }^{1} \mathrm{H}\right.$ COSY; ${ }^{1} \mathrm{H}_{-}{ }^{13} \mathrm{C}$ HSQC $;{ }^{1} \mathrm{H}_{-}{ }^{13} \mathrm{C}$ HMBC) were done using the pulse sequences from the Bruker user library. Waters Xevo TQD mass spectrometer supplied with UPLC Acquity mode (Milford, USA) was employed to carry out ESI-MS analysis. Normal phase column chromatography was done using silica gel (Kieselgel 60, 70-230, and 230-400 mesh, Merck KGaA, Darmstadt, Germany). TLC analysis was done utilizing normal phase silica gel 
precoated plates $\mathrm{F}_{254}$ (Merck, Germany). Detection of TLC spots was done using UV light at $254 \mathrm{~nm}$ and $365 \mathrm{~nm}$ as well as by spraying with $10 \% \mathrm{H}_{2} \mathrm{SO}_{4}$ with subsequent heating on a hot plate at $100{ }^{\circ} \mathrm{C}$.

\section{Isolation of the secondary metabolites from the bioactive fractions}

The $n$-hexane fraction (33 g) of B. rupestris was chromatographed on silica gel (600 g) employing $n$-hexane:EtOAc with increasing polarity to give 23 major fractions. Fraction II was further eluted with a mixture of $n$-hexane: EtOAc (9.0:1.0) from which compound 1 (40 mg) was precipitated as a white amorphous powder. A mixture of compounds 2 and $3(60 \mathrm{mg})$ was precipitated from fraction III as white crystalline needles using the solvent system $n$-hexane:EtOAc (9.0:1.0) as illustrated in Fig. 1.

The dichloromethane fraction of B. rupestris (6 g) was chromatographed on silica gel (300 g) using mixtures of $\mathrm{CH}_{2} \mathrm{Cl}_{2}: \mathrm{CH}_{3} \mathrm{OH}$ with increasing polarity as eluents to afford 26 major fractions. Fraction VI $(70 \mathrm{mg})$ was further eluted with dichloromethane and was subjected to silica gel column using a mixture of $\mathrm{CH}_{2} \mathrm{Cl}_{2}: \mathrm{CH}_{3} \mathrm{OH}$ to give seven subfractions. Subfraction $7(30 \mathrm{mg})$ was eluted with a mixture of $\mathrm{CH}_{2} \mathrm{Cl}_{2}: \mathrm{CH}_{3} \mathrm{OH}$ (9.9:0.1) and purified over preparative TLC which resulted in the separation of compound $4(8 \mathrm{mg})$ that showed strong fluorescent yellow color. Fraction XV was eluted using a mixture of $\mathrm{CH}_{2} \mathrm{Cl}_{2}: \mathrm{CH}_{3} \mathrm{OH}$ (9.6:0.4) from which compound $5(50 \mathrm{mg})$ was precipitated as a yellow powder as shown in Fig. 2.

The EtOAc fraction $(4 \mathrm{~g})$ was applied on the top of 150 g Diaion HP column using water, 50\% methanol, $100 \%$ methanol as the mobile phases. The $50 \%$ methanol fraction $(2 \mathrm{~g})$ was the most promising fraction after comparing its TLC with the other fractions and was applied on the top of $40 \mathrm{~g}$ Sephadex $^{\circ}$ LH 20 and eluted using water and methanol of decreasing polarity to give 16 fractions. Fraction V $(70 \mathrm{mg})$ and fraction VI $(50 \mathrm{mg})$ were eluted using water $100 \%$ and were purified over preparative TLC using $\mathrm{CH}_{2} \mathrm{Cl}_{2}: \mathrm{CH}_{3} \mathrm{OH}$ (8.5:1.5) as the mobile phase to separate compounds $6(6 \mathrm{mg})$ and 7 (5 mg), respectively (Fig. 3).

\section{Spectroscopic data of compounds 1-7}

$\beta$-Amyrin acetate (1)

It was isolated as a white amorphous powder; with $\mathrm{R}_{f}=$ 0.530 in $n$-hexane:EtOAc (9.5:0.5). ${ }^{1} \mathrm{H}$ NMR $(400 \mathrm{MHz}$, $\left.\mathrm{CDCl}_{3}\right),{ }^{13} \mathrm{C}$ NMR $\left(100 \mathrm{MHz}, \mathrm{CDCl}_{3}\right)$ and 2D NMR spectroscopic data are displayed in the Additional file 1: Figure S1).

$\beta$-Sitosterol (2) and Stigmasterol (3)

They were isolated as white crystalline needles; showing $\mathrm{R}_{f}=0.206$ in $n$-hexane:EtOAc (9:1). ${ }^{1} \mathrm{H}$-NMR $(400 \mathrm{MHz}$, $\left.\mathrm{CDCl}_{3}\right),{ }^{13} \mathrm{C}$ NMR $\left(100 \mathrm{MHz}, \mathrm{CDCl}_{3}\right)$ and 2D NMR spectral data are displayed in the Additional file 1: Figure S2.

Scopoletin (4)

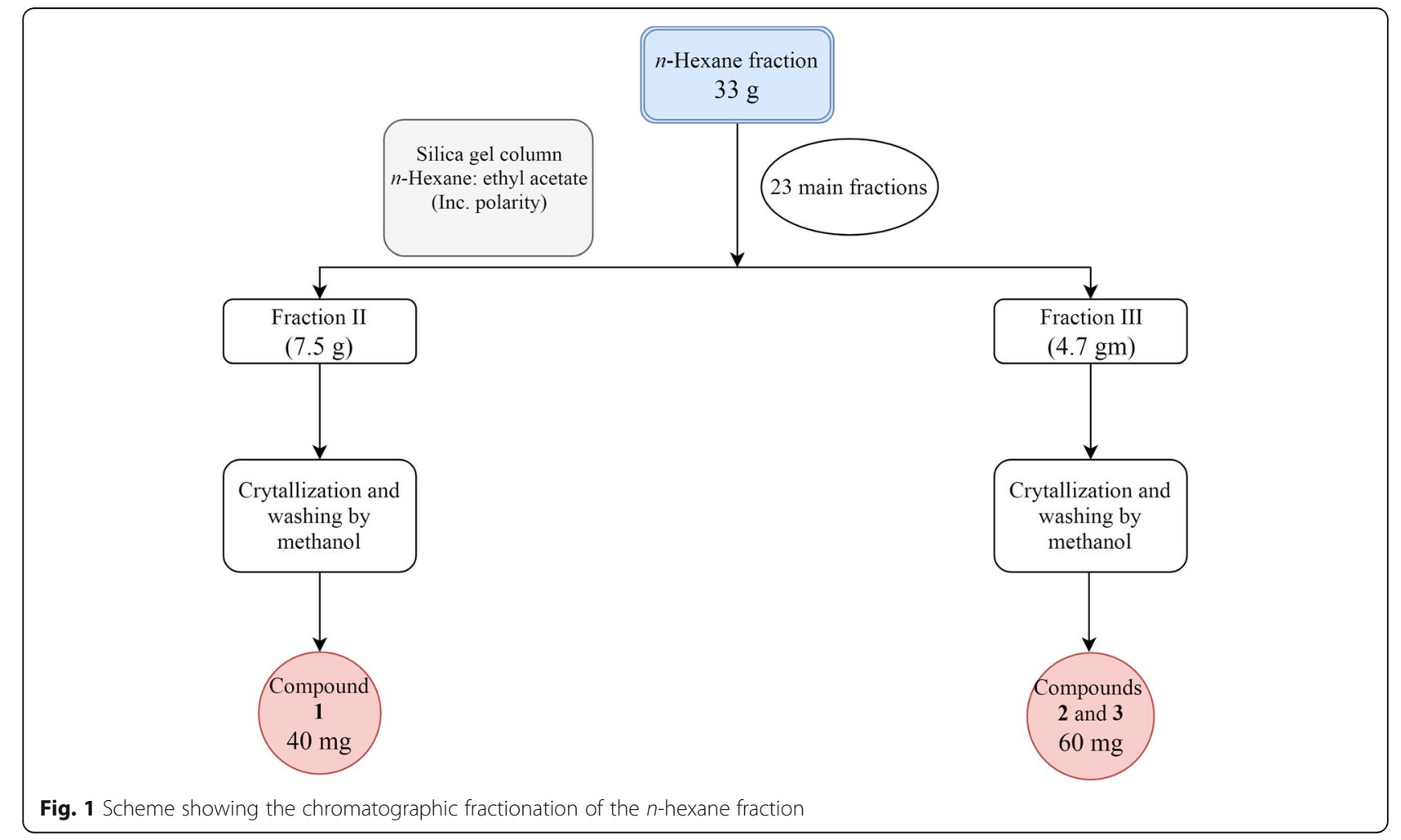




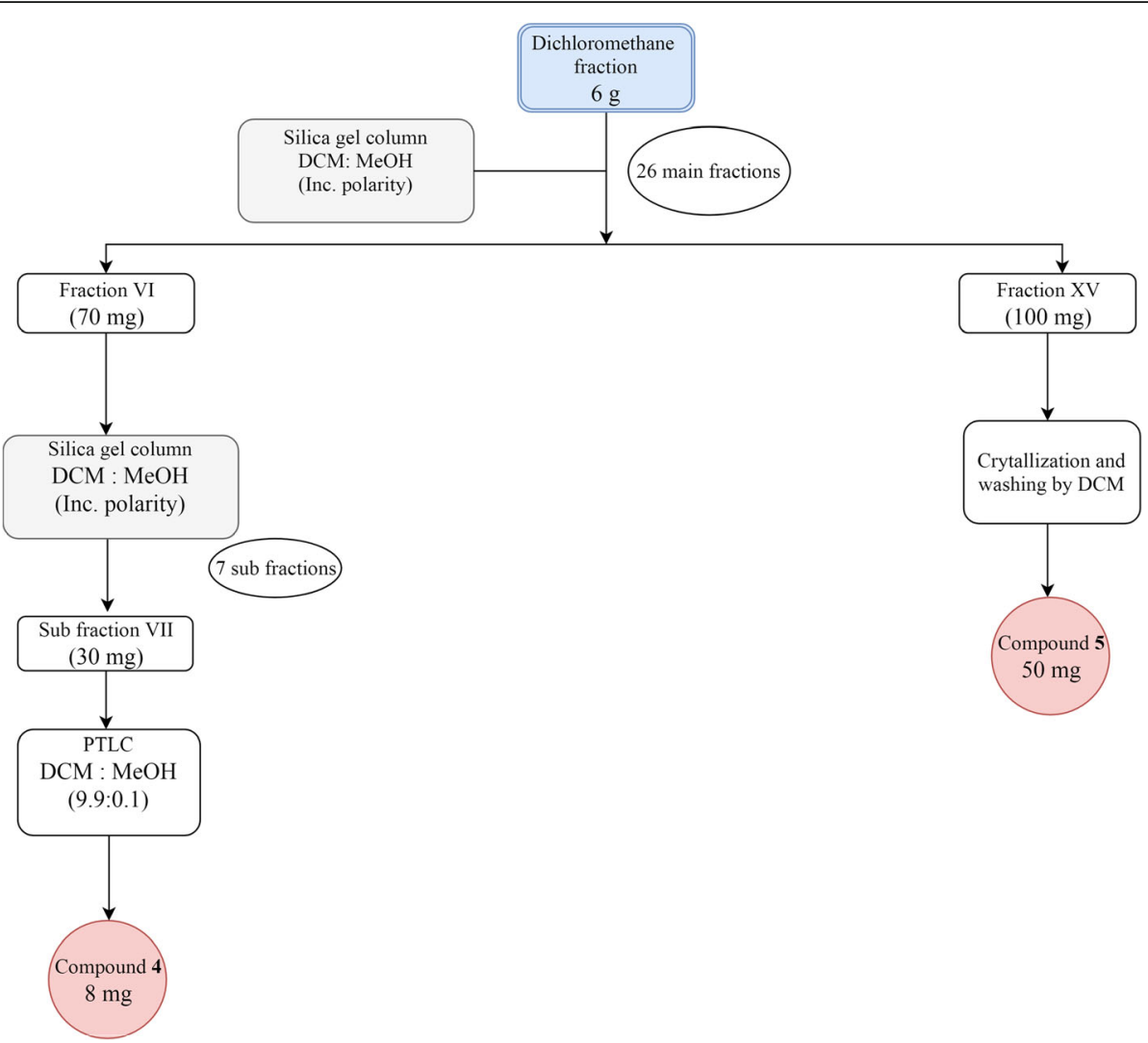

Fig. 2 Scheme showing the chromatographic fractionation of the dichloromethane fraction

It was obtained as a yellow powder; with $\mathrm{R}_{f}=0.630$ in $\mathrm{CH}_{2} \mathrm{Cl}_{2}: \mathrm{CH}_{3} \mathrm{OH}$ (9.9:0.1). ${ }^{1} \mathrm{H}-\mathrm{NMR}\left(400 \mathrm{MHz}, \mathrm{CD}_{3} \mathrm{OD}\right)$ $(\delta \mathrm{ppm}): 7.75(1 \mathrm{H}, d, J=9.1, \mathrm{H}-4), 6.80(1 \mathrm{H}, s, \mathrm{H}-5), 6.45$ $(1 \mathrm{H}, s, \mathrm{H}-8), 5.85(1 \mathrm{H}, d, J=9.1 \mathrm{~Hz}, \mathrm{H}-3), 3.81(3 \mathrm{H}, s$, 6- $\left.\mathrm{OCH}_{3}\right) .{ }^{13} \mathrm{C}$ NMR data $\left(100 \mathrm{MHz}, \mathrm{CD}_{3} \mathrm{OD}\right)(\delta \mathrm{ppm})$ : 166.26 (C-2), 153.86 (C-7), 151.4 (C-6), 146.99 (C-4), 107.65 (C-5), 105.50 (C-3), 104.59, (C-8), $56.03\left(6-\mathrm{OCH}_{3}\right)$. It exhibited a deprotonated molecular ion peak at $\mathrm{m} / \mathrm{z}$ $190.8[\mathrm{M}-\mathrm{H}]^{-}$in ESI-MS negative ion mode, corresponding to the molecular formula $\mathrm{C}_{10} \mathrm{H}_{8} \mathrm{O}_{4}$ (Additional file 1 : Figure S3).

$\beta$-Sitosterol-3-O- $\beta$-D-glucoside (5)

It was isolated as a buff amorphous powder; with $\mathrm{R}_{f}=$ 0.630 in $\mathrm{CH}_{2} \mathrm{Cl}_{2}: \mathrm{CH}_{3} \mathrm{OH}$ (9.2:0.8). ${ }^{1} \mathrm{H}-\mathrm{NMR}(400 \mathrm{MHz}$, DMSO- $\left.d_{6}\right),{ }^{13} \mathrm{C}$ NMR (100 MHz, DMSO- $\left.d_{6}\right)$ and 2D NMR spectroscopic data are displayed in the Additional file 1: Figure S4.

Dihydrodehydrodiconiferyl alcohol 4-O- $\beta$-D-glucoside (6)

It was obtained as a yellowish white amorphous powder; with $\mathrm{R}_{f}=0.259$ in $\mathrm{CH}_{2} \mathrm{Cl}_{2}: \mathrm{CH}_{3} \mathrm{OH}$ (8.5:1.5). ${ }^{1} \mathrm{H}-\mathrm{NMR}$ (400 MHz, CD $\left.{ }_{3} \mathrm{OD}\right),{ }^{13} \mathrm{C}$ NMR data $\left(100 \mathrm{MHz}, \mathrm{CD}_{3} \mathrm{OD}\right)$ are illustrated in Table 4, (Additional file 1: Figure S5).

Dihydrodehydrodiconiferyl alcohol 9-O- $\beta$-D-glucoside (7)

It was obtained as a yellowish white amorphous powder; with $\mathrm{R}_{f}=0.304$ in $\mathrm{CH}_{2} \mathrm{Cl}_{2}: \mathrm{CH}_{3} \mathrm{OH}$ (8.5:1.5). ${ }^{1} \mathrm{H}-\mathrm{NMR}$
(400 MHz, CD $\left.{ }_{3} \mathrm{OD}\right),{ }^{13} \mathrm{C}$ NMR $\left(100 \mathrm{MHz}, \mathrm{CD}_{3} \mathrm{OD}\right)$ and 2D NMR spectroscopic data are displayed in Table 4 and the Additional file 1: Figure S6.

\section{Results}

In vitro assessment of the cytotoxic activity of $B$. rupestris and B. discolor

The cytotoxicity of the total methanol extracts and fractions of both $B$. rupestris and $B$. discolor was evaluated versus HepG2, A549 and MDA-MB-231 cancer cells using doxorubicin as the positive control. Extracts and fractions of both species at $20 \mu \mathrm{g} / \mathrm{mL}$ exhibited no cytotoxic activity against any of the tested cell lines. Noteworthy to mention that doxorubicin showed 91.28, 97.69 and $98.05 \%$ cell growth inhibition against HepG2, MDA-MB-231 and A549, respectively at $2 \mu \mathrm{g} / \mathrm{mL}$. The results are illustrated in Table 1 . Together with the nontoxic effects of all samples towards RBL-2H3 mast cells (see the following section, and Table 2) the results suggested that both species extracts and fractions exhibited no cytotoxicity against the tested cancer cell lines.

\section{In vitro assessment of the anti-allergic activity of $B$. rupestris and $B$. discolor}

The anti-allergic activity of the total methanol extracts and fractions of both $B$. rupestris and $B$. discolor was 


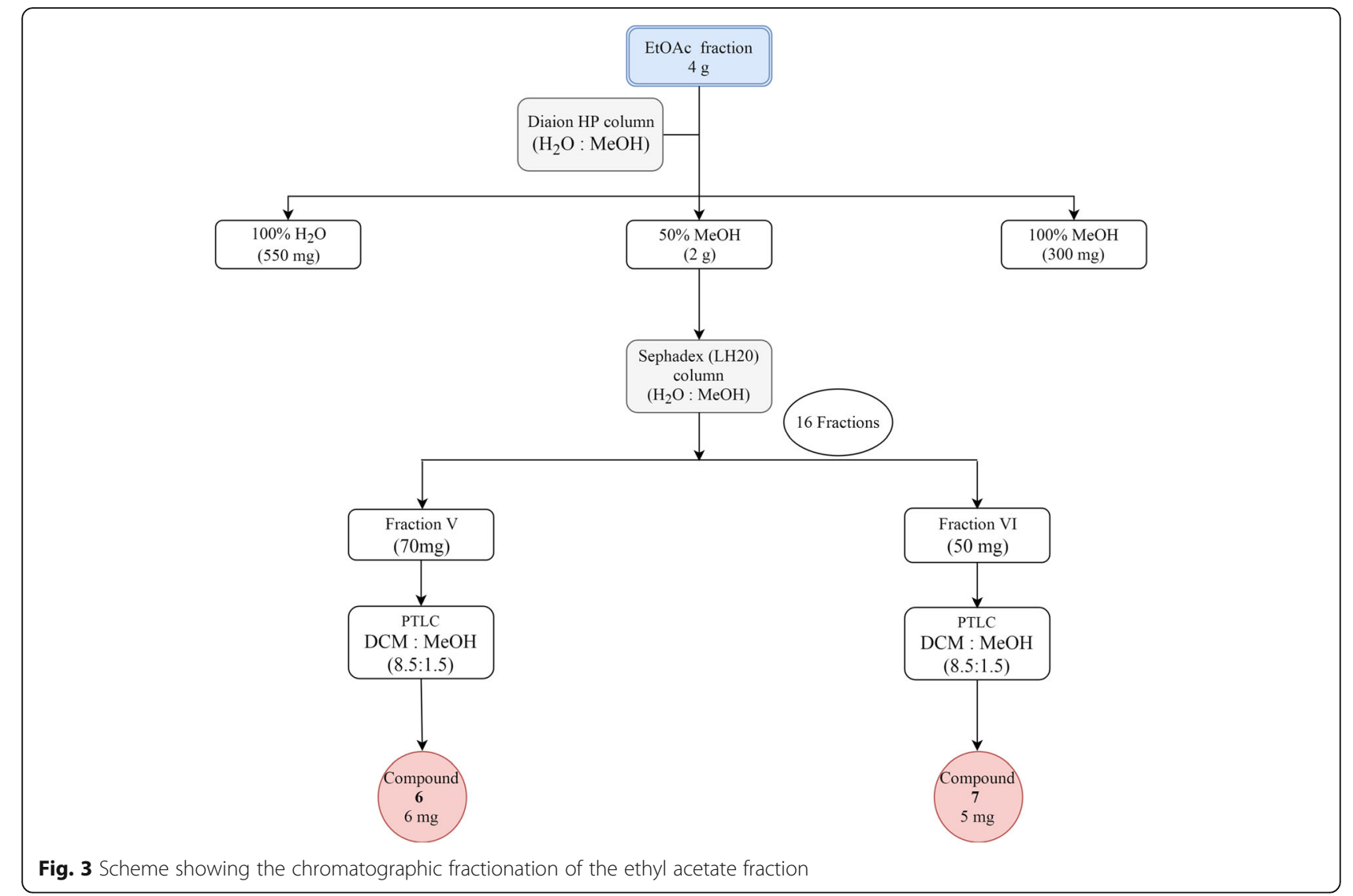

assessed using degranulation assay in RBL-2H3 mast cell model and the results are presented in Table 2. Initially, the cytotoxic effect of all samples was tested against RBL-2H3 cells using MTT viability assay. All samples were found to be nontoxic at $100 \mu \mathrm{g} / \mathrm{mL}$. The samples were subjected to the anti-allergic assay by evaluating their inhibitory effect on $\beta$-hexosaminidase release in RBL-2H3 cells induced by calcium ionophore, A23187. According to our results, B. rupestris and B. discolor crude methanol extracts (BRT 25.7\% and BDT 16.0\% inhibition) and nonpolar $n$-hexane (BRH 39.0\%, BDH 30.3\% inhibition) and dichloromethane fractions (BRD 19.0\%; and BDD 44.0\% inhibition) exhibited significant inhibition of $\beta$-hexosaminidase release in A23187-induced degranulation assay at $100 \mu \mathrm{g} / \mathrm{mL}$ (Table 2). Dexamethasone, a positive control, showed $62.0 \%$ inhibition of $\beta$-hexosaminidase release at $10 \mathrm{nM}$.

In vitro assessment of the anti-inflammatory activity of $B$. rupestris and $B$. discolor

Similarly, the anti-inflammatory activity was determined for the total methanol extracts and fractions of $B$. rupestris and $B$. discolor and the results are presented in Table 3. Both Brachychiton species exhibited a promising inhibitory activity on superoxide anion production as well as elastase release in fMLF-activated human neutrophils indicating their potential applications for the alleviation of both acute and chronic inflammatory disorders. All samples inhibited superoxide anion generation showing $\mathrm{IC}_{50}$ values between 0.78 and $6.25 \mu \mathrm{g} / \mathrm{mL}$ in addition

Table 1 In vitro cytotoxicity of different extracts and fractions of B. rupestris and B. discolor against HepG2, MDA-MB-231 and A549 cell lines

\begin{tabular}{lllllllllll}
\hline Cell line & BRT & BRH & BRD & BRE & BRR & BDT & BDH & BDD & BDE & doxorubicin \\
\hline HepG2 & 1.28 & -2.078 & -8.02 & -8.43 & -13.74 & 1.66 & -7.43 & -16.18 & -6.62 & $91.28 \pm 0.3$ \\
MDA-MB-231 & -15.86 & -9.70 & -18.83 & -25.52 & -23.30 & -6.19 & -6.73 & 13.17 & -20.64 & $97.69 \pm 0.4$ \\
A549 & 0.44 & -0.81 & 7.85 & -8.37 & -0.89 & 12.59 & 8.18 & 14.99 & -6.52 & $98.05 \pm 0.0$ \\
\hline
\end{tabular}

Results are presented as growth inhibition percentage at concentration of $20 \mu \mathrm{g} / \mathrm{mL}$, mean $(n=1)$. Doxorubicin $(2 \mu \mathrm{g} / \mathrm{mL})$ was used as the reference drug, mean $\pm \mathrm{SD}(n=2)$. BRT: B. rupestris total methanol extract; BHT: B. rupestris $n$-hexane fraction; BRD: B. rupestris dichloromethane fraction; BRE: $B$. rupestris ethyl acetate fraction; $\mathrm{BRR}$ : $B$. rupestris remaining $\mathrm{MeOH}(\mathrm{aq})$ fraction; $\mathrm{BDT}$ : $B$. discolor total methanol extract; $\mathrm{BDH}$ : $B$. discolor $n$-hexane fraction; $\mathrm{BDD}$ : $B$. discolor dichloromethane fraction; BDE: $B$. discolor ethyl acetate fraction 
Table 2 Anti-allergic activity of B. rupestris and B. discolor extracts and fractions

\begin{tabular}{llll}
\hline Sample & $\%$ viability, RBL-2H3 & \multicolumn{2}{c}{$\begin{array}{l}\text { \% inhibition of A23187-induced } \\
\text {-hexosaminidase release }\end{array}$} \\
\cline { 2 - 4 } & $100 \mu \mathrm{g} / \mathrm{mL}$ & $3.0 \pm 5.2$ & $25.7 \pm 2.1^{* *}$ \\
\hline BRT & $99.0 \pm 1.7$ & $3.3 \pm 5.8$ & $39.0 \pm 13.1^{* *}$ \\
BRH & $96.7 \pm 4.0$ & $4.3 \pm 7.5$ & $19.0 \pm 4.4^{*}$ \\
BRD & $95.3 \pm 8.1$ & $2.0 \pm 3.5$ & $7.0 \pm 5.2$ \\
BRE & $97.7 \pm 4.0$ & $4.3 \pm 5.1$ & $3.7 \pm 6.4$ \\
BRR & $99.0 \pm 1.7$ & $3.7 \pm 6.4$ & $16.0 \pm 5.0^{*}$ \\
BDT & $99.0 \pm 1.7$ & $4.3 \pm 7.5$ & $30.3 \pm 3.1^{* *}$ \\
BDH & $99.7 \pm 0.6$ & $0.0 \pm 0.0$ & $44.0 \pm 7.8^{* *}$ \\
BDD & $100.0 \pm 0.0$ & $1.7 \pm 2.9$ & $0.3 \pm 0.6$ \\
BDE & $100.0 \pm 0.0$ &
\end{tabular}

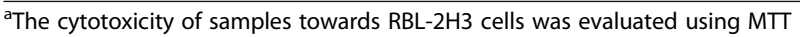
viability assay and none of the samples showed any toxicity; results are presented as mean \pm SD $(n=3)$

${ }^{b}$ Dexamethasone $(10 \mathrm{nM})$ was used as the positive control and inhibited 62.0 $\pm 9.5 \%{ }^{* *}$ of A23187-induced $\beta$-hexosaminidase release in RBL-2H3 cells. Results are presented as mean $\pm \mathrm{SD}(n=3) ;{ }^{*} p<0.05,{ }^{* *} p<0.001$ compared with the control value (A23187 only)

BRT B. rupestris total methanol extract, BRH B. rupestris $n$-hexane fraction, BRD $B$. rupestris dichloromethane fraction, BRE $B$. rupestris ethyl acetate fraction, $\mathrm{BRR} B$. rupestris remaining $\mathrm{MeOH}(\mathrm{aq})$ fraction, $\mathrm{BDT} B$. discolor total methanol extract, $\mathrm{BDH} B$. discolor $n$-hexane fraction, BDD $B$. discolor dichloromethane fraction, BDE $B$. discolor ethyl acetate fraction

Table 3 Effect of the total extracts and fractions of B. rupestris and $B$. discolor on superoxide anion generation and elastase release in $\mathrm{fMLF} / \mathrm{CB}$-induced human neutrophils

\begin{tabular}{lll}
\hline Sample & $\begin{array}{l}\text { Superoxide anion generation }{ }^{\mathrm{a}} \\
\mid C_{50}(\mu \mathrm{g} / \mathrm{mL})^{\mathrm{b}}\end{array}$ & $\begin{array}{l}\text { Elastase release }^{\mathrm{a}} \\
\mathrm{IC}_{50}(\mu \mathrm{g} / \mathrm{mL})^{\mathrm{b}}\end{array}$ \\
\hline BRT & $4.92 \pm 1.47$ & $3.82 \pm 0.55$ \\
BRH & $5.69 \pm 0.80$ & $3.73 \pm 1.16$ \\
BRD & $2.99 \pm 0.73$ & $1.98 \pm 1.54$ \\
BRE & $6.25 \pm 3.10$ & $2.71 \pm 0.79$ \\
BRR & $3.01 \pm 1.91$ & $>10^{c}$ \\
BDT & $4.73 \pm 0.97$ & $5.37 \pm 1.23$ \\
BDH & $6.25 \pm 2.18$ & $6.04 \pm 2.32$ \\
BDD & $0.78 \pm 0.29$ & $1.57 \pm 0.84$ \\
BDE & $5.22 \pm 1.35$ & $2.95 \pm 1.08$ \\
genistein & $0.41 \pm 0.09$ & $4.41 \pm 1.99$
\end{tabular}

${ }^{\mathrm{a}} \mathrm{C}_{50}$ values, results are presented as mean $\pm \mathrm{SD}(n=3)$, compared with the control value (formyl-methionyl-leucyl-phenylalanine/cytochalasin $B, f M L F / C B$ ) ${ }^{\mathrm{b}}$ Concentration necessary for $50 \%$ inhibition $\left(\mathrm{IC}_{50}\right)$

${ }^{\mathrm{C}} \mathrm{BRR}$ exerted significant inhibitory activity in superoxide anion generation $\left(49.6 \pm 2.9 \%,{ }^{* *} p<0.001\right)$ at $10 \mu \mathrm{g} / \mathrm{mL}$. BRT B. rupestris total methanol extract, $\mathrm{BRH} B$. rupestris $n$-hexane fraction, BRD $B$. rupestris dichloromethane fraction, $\mathrm{BRE} B$. rupestris ethyl acetate fraction, $\mathrm{BRR} B$. rupestris remaining $\mathrm{MeOH}(\mathrm{aq})$ fraction, BDT $B$. discolor total methanol extract, $\mathrm{BDH} B$. discolor $n$-hexane fraction, $\mathrm{BDD} B$. discolor dichloromethane fraction, $\mathrm{BDE} B$. discolor ethyl acetate fraction to inhibition of elastase release showing $\mathrm{IC}_{50}$ values ranging from 1.57 to $>10 \mu \mathrm{g} / \mathrm{mL}$ (Table 3). The most potent fractions, dichloromethane fractions of $B$. rupestris (BRD) and B. discolor (BDD) inhibited superoxide anion generation with $\mathrm{IC}_{50}$ values $2.99 \mu \mathrm{g} / \mathrm{mL}$ (BRD) and $0.78 \mu \mathrm{g} / \mathrm{mL}(\mathrm{BDD})$, and inhibited elastase release with $\mathrm{IC}_{50}$ values $1.98 \mu \mathrm{g} / \mathrm{mL}$ (BRD) and $1.57 \mu \mathrm{g} / \mathrm{mL}$ (BDD). Such activities indicated comparable or even better inhibitory potential than that of genistein (superoxide $\mathrm{IC}_{50}$ $0.41 \mu \mathrm{g} / \mathrm{mL}$ and elastase $\mathrm{IC}_{50} 4.41 \mu \mathrm{g} / \mathrm{mL}$ ), a known anti-inflammatory natural product $[50,51]$. The dichloromethane fractions (BRD and BDD) were capable of almost completely abolishing oxidative burst and degranulation in fMLF-activated human neutrophils at $10 \mu \mathrm{g} / \mathrm{mL}$ (data not shown). Meanwhile, the ethyl acetate fraction of both species showed anti-inflammatory activity by inhibiting elastase release showing $\mathrm{IC}_{50}$ values of $2.71 \mu \mathrm{g} / \mathrm{mL}$ for B. rupestris (BRE) and $2.95 \mu \mathrm{g} / \mathrm{mL}$ for B. discolor (BDE).

\section{Phytochemical investigations}

In-depth phytochemical investigation was performed on the most bioactive fractions of $B$. rupestris leaves including the $n$-hexane, the dichloromethane and ethyl acetate fractions that showed the highest anti-allergic and anti-inflammatory activities. Three compounds were isolated and structurally elucidated from the $n$-hexane fraction which were $\beta$-amyrin acetate (1) [29], $\beta$-sitosterol (2) [52], stigmasterol (3) [52]. Meanwhile, two compounds were obtained from the dichloromethane fraction including scopoletin (4) $[53,54]$ and $\beta$-sitosterol-3-O- $\beta$-D-glucoside (5) [55] which were isolated for the first time from $B$. rupestris leaves. Furthermore, two neolignans were obtained from the ethyl acetate fraction, dihydrodehydrodiconiferyl alcohol 4-O- $\beta$-D-glucoside (6) [56] and dihydrodehydrodiconiferyl alcohol 9-O- $\beta$-D-glucoside (7) [57] which were isolated for the first time from the genus (Fig. 4). Their structures were fully elucidated using $1 \mathrm{D}$ and 2D NMR techniques and they were further ascertained by comparing their data with previously reported data in literature.

Dihydrodehydrodiconiferyl alcohol 4-O- $\beta$-D-glucoside (6) was isolated as a yellowish white amorphous powder. ${ }^{1} \mathrm{H}-\mathrm{NMR}$ of $(\mathbf{6})$ revealed the presence of a 1,2,4-trisubstituted benzene ring with signals at $\delta_{\mathrm{H}} 7.03(d, J=1.84 \mathrm{~Hz})$, $7.14(d, J=8.43 \mathrm{~Hz})$ and $6.93(d d, J=8.31,2.03 \mathrm{~Hz})$ for $\mathrm{H}-2, \mathrm{H}-5$ and $\mathrm{H}-6$, respectively, each integrated for one proton. Also, a 1,2,3,5-tetrasubstituted benzene ring was presented by two broad singlet signals at $\delta_{\mathrm{H}} 6.73\left(\mathrm{H}-2^{\prime}\right)$ and $6.72\left(\mathrm{H}-6^{\prime}\right)$. The spectrum revealed the existence of a hydroxypropyl group showing three signals at $\delta_{\mathrm{H}} 2.63(t$, H-7 $), 1.82$ ( $\left.m, \mathrm{H}-8^{\prime}\right), 3.57\left(t, \mathrm{H}-9^{\prime}\right)$. Furthermore, a methine-methine-methylene group $\left(\mathrm{CH}-\mathrm{CH}-\mathrm{CH}_{2}\right)$ appeared at $\delta_{\mathrm{H}} 5.56(d, J=5.85, \mathrm{H}-7), 3.44(m, \mathrm{H}-8), 3.80$, $3.75(m, m, \mathrm{H}-9)$. The presence of $\beta$-D-glucose was 

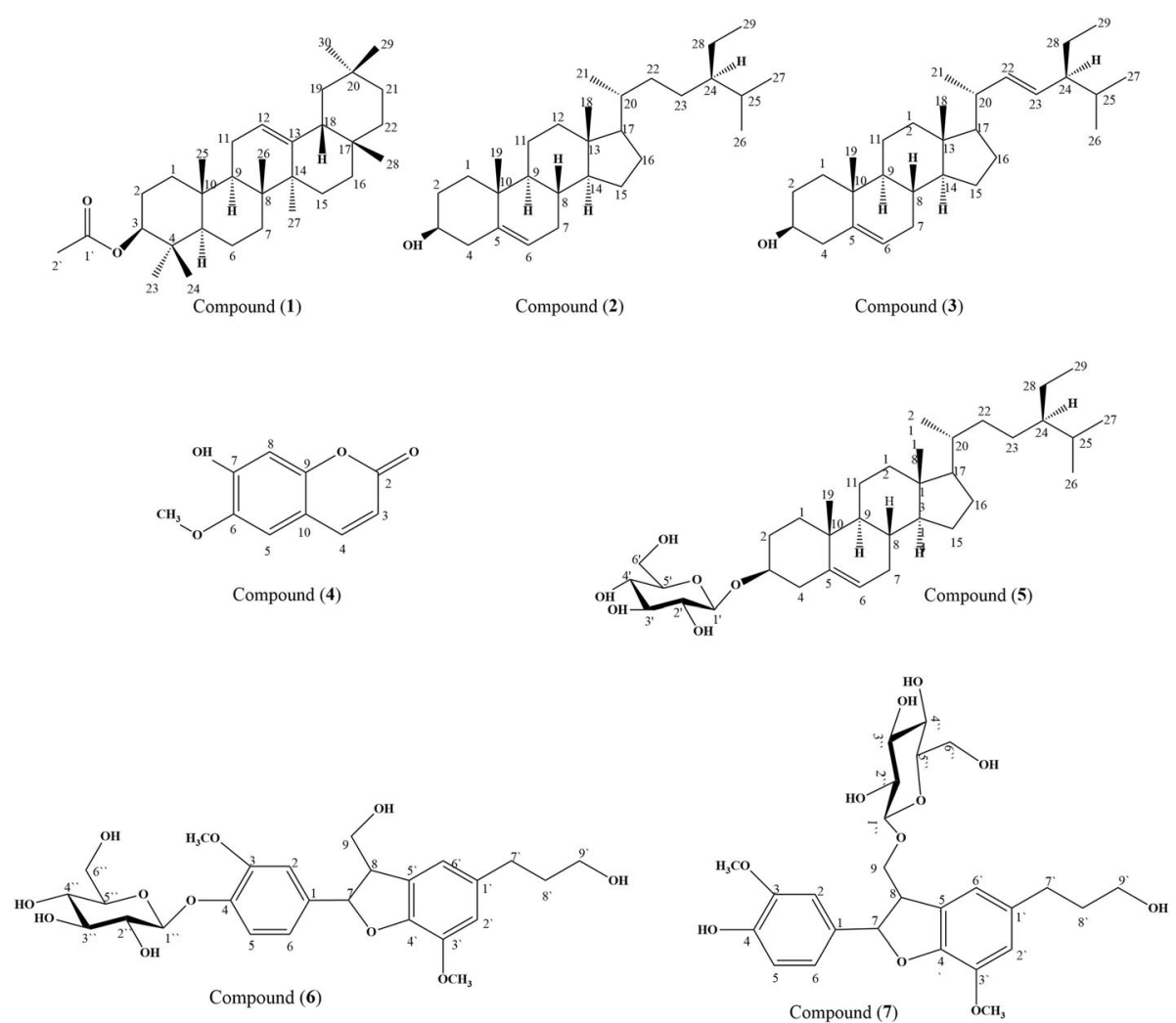

Fig. 4 Structures of identified compounds from $n$-hexane, dichloromethane and ethyl acetate fractions of B. rupestris

proposed by the appearance of anomeric proton at $\delta_{\mathrm{H}}$ 4.88 and other sugar protons at 3.39-3.85. Two singlet signals each integrated for three protons at $\delta_{\mathrm{H}} 3.87$ and 3.83 were attributed to two methoxy groups. ${ }^{13} \mathrm{C}-\mathrm{NMR}$ spectrum of compound (6) showed the presence of five aromatic methines and seven quaternary aromatic carbons signals attributed to two benzene rings at $\delta_{\mathrm{C}} 111.19$, $117.95,119.37,114.19,118.04,137.09,150.9,147.6$, 138.37, 145.24, 147.6, 129.58. Downfield shifts of C-3 (150.9), C-4 (147.6), C-3' (145.24), C-4' (147.6) indicated their attachment to oxygenated functional groups. A signal at $\delta_{\mathrm{C}} 102.78$ was attributed to the anomeric carbon of glucose unit and the other sugar carbons appeared at $74.90,77.84,71.34,78.19$ and 62.51 . The two signals at $\delta_{\mathrm{C}}$ 56.79 and 56.71 represented two methoxy groups. Other aliphatic signals appeared at $\delta_{\mathrm{C}} 88.48,65.07,62.22,55.68$, 35.84 and 32.89 . The HMBC spectrum showed that the methoxy group at $\delta_{\mathrm{C}} 56.79$ was placed at C-3 (150.9) and the methoxy group at $\delta_{\mathrm{C}} 56.71$ was placed at $\mathrm{C}-3^{\prime}$ (145.24). Also, it showed a correlation between C-6, C-2 with $\mathrm{H}-7$; C-6', C-2' with $\mathrm{H}-7^{\prime}$; and C-9' with $\mathrm{H}-\mathrm{7}^{\prime}$. The correlation between $\mathrm{C}-4$ with $\mathrm{H}-1$ " supported the presence of the sugar at C-4. From the displayed data (Table 4) and through comparison with the previously reported literature [56], compound (6) was identified as dihydrodehydrodiconiferyl alcohol 4-O- $\beta$-D-glucoside which was the first time to be reported in the genus.

Dihydrodehydrodiconiferyl alcohol 9-O- $\beta$-D-glucoside (7) was isolated as a yellowish white amorphous powder. The ${ }^{1} \mathrm{H}-\mathrm{NMR}$ and ${ }^{13} \mathrm{C}-\mathrm{NMR}$ data for this compound were similar to compound (6) suggesting the same neolignan nucleus; the two compounds differ in the position of the glucose moiety. The HMBC spectrum revealed the correlation between $\mathrm{C}-9$ with $\mathrm{H}-1$ " which supported the attachment of the sugar at C-9. The downfield shift of C-9 at $\delta_{C} 72.46$ also supported the attachment of the sugar at C-9 [57] (Table 4).

\section{In vitro assessment of the cytotoxic activity of the isolated compounds}

Additionally, the cytotoxic activity of the compounds obtained from the $n$-hexane and dichloromethane fractions of $B$. rupestris was examined using different concentrations $(20,10,5,2.5 \mu \mathrm{g} / \mathrm{mL})$ of these compounds on the same cell lines utilized in the determination of the cytotoxic effect of the total extracts and subsequent fractions. The isolated compounds showed no cytotoxicity against hepatoma HepG2, breast MDA-MB-231 and lung A549 cancer cell lines with growth inhibition below 20\%. The results are illustrated in Table 5 . 
Table $4{ }^{1} \mathrm{H}$ - and ${ }^{13} \mathrm{C}$-NMR spectroscopic data for 6 and 7

\begin{tabular}{|c|c|c|c|c|}
\hline & Dihydro & eryl alcohol 4-O- $\beta$-D-glucoside (6) & Dihydro & alcohol 9-O- $\beta$-D-glucoside (7) \\
\hline & $\delta_{C}$ & $\delta_{\mathrm{H}}$ (Mult, Int), $J$ in $\mathrm{Hz}$ & $\delta_{C}$ & $\delta_{\mathrm{H}}$ (Mult, Int), $J$ in $\mathrm{Hz}$ \\
\hline 1 & 137.09 & & 134.67 & \\
\hline 2 & 111.19 & $7.03(d, 1 H), 1.84$ & 110.71 & $7.02(d, 1 H), 2.01$ \\
\hline 3 & 150.9 & & 149.05 & \\
\hline 4 & 147.6 & & 147.48 & \\
\hline 5 & 117.95 & $7.14(d, 1 H), 8.43$ & 116.08 & $6.78(d, 1 H), 8.09$ \\
\hline 6 & 119.37 & $6.93(d d, 1 H), 8.31,2.03$ & 119.72 & $6.89(d d, 1 H), 8.28,2$ \\
\hline 7 & 88.48 & $5.56(d, 1 H), 5.85$ & 88.98 & $5.62(d, 1 H), 6.21$ \\
\hline 8 & 55.68 & $3.44(m, 1 \mathrm{H})$ & 53.28 & $3.69(m, 1 \mathrm{H})$ \\
\hline 9 & 65.07 & $3.80,3.75(m, m, 2 \mathrm{H})$ & 72.46 & $4.23,3.79(d d, m, 2 \mathrm{H})$ \\
\hline $3-\mathrm{OCH}_{3}$ & 56.79 & $3.87(\mathrm{~s}, 3 \mathrm{H})$ & 56.44 & $3.85(s, 3 \mathrm{H})$ \\
\hline $1^{\prime}$ & 138.37 & & 136.64 & \\
\hline $2^{\prime}$ & 114.19 & $6.73(s, 1 \mathrm{H})$ & 114.19 & $6.75(s, 1 \mathrm{H})$ \\
\hline $3^{\prime}$ & 145.24 & & 145.21 & \\
\hline $4^{\prime}$ & 147.6 & & 147.48 & \\
\hline $5^{\prime}$ & 129.58 & & 129.56 & \\
\hline $6^{\prime}$ & 118.04 & $6.72(s, 1 \mathrm{H})$ & 118.21 & $6.80(s, 1 \mathrm{H})$ \\
\hline $7^{\prime}$ & 32.89 & $2.63(t, 2 \mathrm{H})$ & 32.89 & $2.65(t, 2 \mathrm{H})$ \\
\hline $8^{\prime}$ & 35.84 & $1.82(m, 2 \mathrm{H})$ & 35.82 & $1.84(m, 2 \mathrm{H})$ \\
\hline $9^{\prime}$ & 62.22 & $3.57(t, 2 \mathrm{H})$ & 62.23 & $3.59(\mathrm{t}, 2 \mathrm{H})$ \\
\hline $3^{\prime}-\mathrm{OCH}_{3}$ & 56.71 & $3.83(5,3 \mathrm{H})$ & 56.77 & $3.88(s, 3 \mathrm{H})$ \\
\hline $1 "$ & 102.78 & 4.88 (covered by solvent, 1H) & 104.57 & $4.38(d, 1 H), 7.79$ \\
\hline $2^{\prime \prime}$ & 74.90 & $3.48(m, 1 \mathrm{H})$ & 75.18 & $3.25(m, 1 \mathrm{H})$ \\
\hline $3 "$ & 77.84 & $3.39(m, 1 \mathrm{H})$ & 78.07 & $3.31(m, 1 \mathrm{H})$ \\
\hline $4 "$ & 71.34 & $3.39(m, 1 H)$ & 71.66 & $3.31(m, 1 \mathrm{H})$ \\
\hline $5^{\prime \prime}$ & 78.19 & $3.39(m, 1 \mathrm{H})$ & 78.26 & $3.31(m, 1 \mathrm{H})$ \\
\hline $6 "$ & 62.51 & $3.85,3.69(m, 2 \mathrm{H})$ & 62.81 & $3.88,3.70(m 2 \mathrm{~m})$ \\
\hline
\end{tabular}

NMR data $(\delta)$ were measured ${ }^{1} \mathrm{H}-\mathrm{NMR}\left(400 \mathrm{MHz}, \mathrm{CD}_{3} \mathrm{OH}\right)$ and ${ }^{13} \mathrm{C}-\mathrm{NMR}$ data $\left(100 \mathrm{MHz}, \mathrm{CD}_{3} \mathrm{OH}\right)$

Doxorubicin was employed as a positive control and exhibited a strong cytotoxic effect against HepG2 ( $\mathrm{IC}_{50}$ $0.49 \mu \mathrm{g} / \mathrm{mL})$, MDA-MB-231 $\left(\mathrm{IC}_{50} 0.68 \mu \mathrm{g} / \mathrm{mL}\right)$ and A549 $\left(\mathrm{IC}_{50} 0.13 \mu \mathrm{g} / \mathrm{mL}\right)$ cells.

\section{In vitro assessment of the anti-allergic activity of the isolated compounds}

To ascertain, whether the isolated compounds might be responsible for the anti-allergic activity observed in Brachychiton sp. crude extracts and nonpolar fractions, the isolated compounds were subjected to degranulation assay in RBL-2H3 mast cell model. The results are presented in Table 6. MTT viability assay was used to evaluate the potential toxic effects against RBL-2H3 cells. A mixture of $\beta$-sitosterol (2) and stigmasterol (3) (200 and $100 \mu \mathrm{g} / \mathrm{mL}$ ) was considered toxic (viability below 85\%). According to our results, scopoletin (4) showed $23.0 \%$ inhibition of A23187-induced and $30.0 \%$ of antigen- induced degranulation at $500 \mu \mathrm{M}$. Dihydrodehydrodiconiferyl alcohol 9-O- $\beta$-D-glucoside (7) showed only weak inhibitory effect in the A23187-induced assay (16.3\% at $100 \mu \mathrm{M}$ and $18.0 \%$ at $500 \mu \mathrm{M})$. Dexamethasone $(10 \mathrm{nM})$ was utilized as the positive control and inhibited $\beta$-hexosaminidase release by $93.7 \%$.

\section{In vitro assessment of the anti-inflammatory activity of the isolated compounds}

The anti-inflammatory effect of the isolated compounds was determined to understand whether any of these compounds might be accountable for the potent activity of $B$. rupestris crude extract and its fractions. The results are illustrated in Table 7. According to the results, scopoletin (4) was found to significantly inhibit elastase release in fMLF-induced human neutrophils by $22.8 \%$ at $10 \mu \mathrm{M}$. Genistein, natural tyrosine kinase inhibitor [50, 51], was used as the positive control and caused significant 
Table 5 Cytotoxic activity of the isolated compounds

\begin{tabular}{llll}
\hline Cell line & $\begin{array}{l}\text { Conc. } \\
(\mu \mathrm{g} /\end{array}$ & \% Inhibition & \\
\cline { 4 - 4 } $\mathrm{mL})$ & $\beta$-amyrin acetate (1) & Scopoletin (4) \\
\hline HepG2 & 20 & $12.1 \pm 3.4$ & $11.4 \pm 2.1$ \\
& 10 & $16.0 \pm 0.3$ & $6.5 \pm 1.2$ \\
& 5 & $20.4 \pm 2.3$ & $0.9 \pm 0.1$ \\
& 2.5 & $8.23 \pm 0.7$ & $5.9 \pm 1.2$ \\
MDA-MB-231 & 20 & $-19.6 \pm 1.2$ & $8.2 \pm 1.0$ \\
& 10 & $-13.9 \pm 1.2$ & $6.0 \pm 0.3$ \\
& 5 & $-5.5 \pm 1.2$ & $10.7 \pm 9.8$ \\
& 2.5 & $7.0 \pm 0.1$ & $15.5 \pm 0.3$ \\
A549 & 20 & $2.2 \pm 0.5$ & $7.9 \pm 0.4$ \\
& 10 & $9.0 \pm 1.0$ & $14.9 \pm 0.4$ \\
& 5 & $10.8 \pm 0.5$ & $14.6 \pm 0.5$ \\
& 2.5 & $0.4 \pm 0.7$ & $14.3 \pm 0.7$
\end{tabular}

Results are presented as cell growth inhibition percentage at concentrations of 2.5 to $20 \mu \mathrm{g} / \mathrm{mL}$, mean $\pm \mathrm{SD}(n=3)$. Doxorubicin was used as the positive control and exerted significant cell viability inhibitory effects against HepG2 (IC $0.49 \mu \mathrm{g} / \mathrm{mL})$, MDA-MB-231 (IC $50.68 \mu \mathrm{g} / \mathrm{mL})$

suppression of superoxide anion generation $\left(\mathrm{IC}_{50}\right.$ $1.16 \mu \mathrm{M})$ and elastase release $\left(\mathrm{IC}_{50} 21.51 \mu \mathrm{M}\right)$.

\section{Discussion}

RBL-2H3 are mast cells that greatly affect the development of allergic response [58]. Upon activation by antigen or A23187 (calcium ionophore), mast cells produce histamine in addition to other mediators that immediately initiate hypersensitivity reactions. $\beta$-Hexosaminidase represents an important mast cells degranulation marker that is commonly used for the assessment of anti-allergic activity [59].

The anti-allergic activity of the crude extracts as well as $n$-hexane and dichloromethane fractions of $B$. rupestris and $B$. discolor leaves (Table 2) might be attributed to the presence of many active constituents from their non-polar fractions. Sterols, sterol glycosides, coumarin, and triterpenes were isolated and identified in B. rupestris leaves. Lanosterol, lupeol, $\beta$-amyrin, $\beta$-amyrin acetate and oleanolic acid were previously reported from $B$. discolor leaves by Kassem et al. [23]. These triterpenes were reported to exert a potent anti-allergic activity [60$62]$ including $\beta$-amyrin that was previously documented to exhibit mast cell membrane stabilization [30]. The anti-allergic activity of triterpenes might be attributed to the suppression of secretion of histamine and interleukins (IL-2, IL-4) from mast cells [62]. Also, $\beta$-sitosterol was reported to possess anti-allergic activity and might have therapeutic potential in allergic asthma [63, 64]. It was suggested that $\beta$-sitosterol and its glycoside inhibited the release of IL- 4 so it could act as an immune modulator to relieve symptoms associated with seasonal allergic response [65]. However, we did not observe any significant effect of either $\beta$-amyrin acetate (1), the mixture of $\beta$-sitosterol (2) and stigmasterol (3) or $\beta$-sitosterol glycoside (5) in degranulation assay using the RBL-2H3 mast cell model (Table 6). Meanwhile, scopoletin (4) and dihydrodehydrodiconiferyl alcohol 9-O- $\beta$-D-glucoside (7) showed inhibitory activity on degranulation in RBL-2H3 cells.

Regarding the in vitro anti-inflammatory activity, neutrophils exert a vital role in host's defenses versus the attack by microorganisms and in the pathogenesis of various inflammatory diseases [66]. In response to stimuli, such as fMLF, the activated neutrophils secrete a series of inflammatory mediators such as superoxide anion $\left(\mathrm{O}_{2}{ }^{-}\right)$and elastase which are major contributors to the destruction of tissue in inflammatory response [67]. We observed that the crude extracts and fractions of $B$. rupestris and B. discolor leaves (Table 3) exerted potent anti-inflammatory activity in human neutrophils. Many studies supported the anti-inflammatory activity

Table 6 Anti-allergic activity of compounds isolated from B. rupestris

\begin{tabular}{|c|c|c|c|c|c|}
\hline \multirow[t]{2}{*}{ Sample } & \multicolumn{2}{|c|}{$\%$ viability, $\mathrm{RBL}-2 \mathrm{H} 3^{\mathrm{a}}$} & \multicolumn{3}{|c|}{$\%$ inhibition of $A 23187$-induced $\beta$-hexosaminidase release } \\
\hline & $100 \mu \mathrm{M}$ & $500 \mu \mathrm{M}$ & $10 \mu \mathrm{M}$ & $100 \mu \mathrm{M}$ & $500 \mu \mathrm{M}$ \\
\hline$\beta$-amyrin acetate (1) & $98.3 \pm 2.9$ & c & $0.3 \pm 0.6$ & $0.7 \pm 1.2$ & c \\
\hline scopoletin (4) & $96.0 \pm 4.0$ & $93.7 \pm 6.5$ & $3.7 \pm 4.7$ & $13.7 \pm 8.0$ & $23.0 \pm 8.0^{* * d}$ \\
\hline$\beta$-sitosterol-3-O- $\beta$-D-glucoside (5) & $96.0 \pm 1.0$ & c & $5.0 \pm 5.6$ & $7.7 \pm 3.8$ & $c$ \\
\hline dihydrodehydrodiconiferyl alcohol 4-O- $\beta$-D-glucoside (6) & $97.3 \pm 2.5$ & e & $7.0 \pm 10.4$ & $12.7 \pm 7.6$ & e \\
\hline dihydrodehydrodiconiferyl alcohol 9-0- $\beta$-D-glucoside (7) & $97.7 \pm 2.1$ & $95.3 \pm 4.2$ & $3.3 \pm 4.2$ & $16.3 \pm 5.5^{*}$ & $18.0 \pm 8.7^{*}$ \\
\hline
\end{tabular}

A mixture of $\beta$-sitosterol (2) and stigmasterol (3) was toxic towards RBL-2H3 cells at the concentration of $200 \mu \mathrm{g} / \mathrm{mL}(73.7 \pm 11.7 \%$ viability) and $100 \mu \mathrm{g} / \mathrm{ml}(78.7 \pm$ $11.6 \%$ viability) and inactive at the concentration of $10 \mu \mathrm{g} / \mathrm{mL}(5.0 \% \pm 5.0 \%$ inhibition) in A23187-induced degranulation assay

${ }^{\text {a }}$ The cytotoxicity of samples to RBL-2H3 was evaluated using MTT viability assay; results are presented as mean \pm SD $(n=3)$

${ }^{b}$ Dexamethasone $(10 \mathrm{nM})$ was used as the positive control and inhibited $93.7 \pm 1.5 \%{ }^{* *}$ of $\mathrm{A} 23187$-induced $\beta$-hexosaminidase release in RBL-2H3 cells. Results are presented as mean \pm SD $(n=3) ;{ }^{*} p<0.05,{ }^{* *} p<0.001$ compared with the control value (A23187 only)

'Precipitate was formed upon the addition into the medium at the concentration of $500 \mu \mathrm{M}$, therefore the result could not be justified

${ }^{\mathrm{d}}$ Scopoletin $(500 \mu \mathrm{M})$ exerted $30.0 \pm 7.1 \%$ inhibition of antigen-induced $\beta$-hexosaminidase release $(\operatorname{mean} \pm \mathrm{SD}, n=2)$

e Dihydrodehydrodiconiferyl alcohol $4-O-\beta$-D-glucoside was not tested at the concentration of $500 \mu \mathrm{M}$, however, it was nontoxic towards RBL-2H3 cells $(96.0 \pm 6.9 \%$ viability) and inactive in A23187-induced degranulation assay (10.0 $\pm 4.6 \%$ inhibition) at the concentration of $200 \mu \mathrm{M}$ 
Table 7 Effect of pure compounds on superoxide anion generation and elastase release in fMLF/CB-induced human neutrophils

\begin{tabular}{|c|c|c|}
\hline \multirow[t]{2}{*}{ Sample } & $\begin{array}{l}\text { Superoxide anion } \\
\text { generation }\end{array}$ & $\begin{array}{l}\text { Elastase } \\
\text { release }^{a}\end{array}$ \\
\hline & $I_{50}(\mu M)^{b}$ & $\mathrm{IC}_{50}(\mu \mathrm{M})^{\mathrm{b}}$ \\
\hline$\beta$-amyrin acetate (1) & $>10$ & $>10$ \\
\hline scopoletin (4) & $>10$ & $>10^{c}$ \\
\hline$\beta$-sitosterol-3-O- $\beta$-D-glucoside (5) & $>10$ & $>10$ \\
\hline $\begin{array}{l}\text { dihydrodehydrodiconiferyl } \\
\text { alcohol 4-O- } \beta \text {-D-glucoside (6) }\end{array}$ & $>10$ & $>10$ \\
\hline $\begin{array}{l}\text { dihydrodehydrodiconiferyl } \\
\text { alcohol 9-O- } \beta \text {-D-glucoside (7) }\end{array}$ & $>1^{d}$ & $>1^{d}$ \\
\hline genistein & $1.16 \pm 0.12$ & $21.51 \pm 6.50$ \\
\hline
\end{tabular}

${ }^{a} C_{50}$ values, results are presented as mean $\pm \mathrm{SD}(n=3-4)$, compared with the control value (formyl-methionyl-leucyl-phenylalanine/cytochalasin B, fMLF/CB) ${ }^{\mathrm{b}}$ Concentration necessary for $50 \%$ inhibition $\left(\mathrm{IC}_{50}\right)$

'Scopoletin (4) exerted significant inhibitory activity in elastase release assay $\left(22.8 \pm 15.3 \%,{ }^{*} p<0.05\right)$ at $10 \mu \mathrm{M}$

${ }^{\mathrm{d}}$ Dihydrodehydrodiconiferyl alcohol 9-O- $\beta$-D-glucoside (10) was used at the final concentration of $1 \mu \mathrm{M}$ due to solubility issues

of sterols and their glycosides [68-70]. They induce immunomodulatory response that affects inflammatory mediators [71, 72]. They were also reported to possess potent in vivo anti-inflammatory activity with the concomitant reduction of edema and inflammation in rats [73]. Various studies confirmed the anti-inflammatory activity of triterpenes including $\beta$-amyrin and $\beta$-amyrin acetate $[29,74-76]$. Coumarins also were found to have anti-inflammatory activity by inhibiting different inflammatory mediators such as cyclooxygenase-2, nitric oxide, tumor necrosis factor- $\alpha$ and interleukins [77-79]. Neolignans were reported to exert anti-inflammatory effects by suppressing superoxide anion generation and elastase release [80], they also exhibited nitric oxide (NO) and tumor necrosis factor- $\alpha$ (TNF- $\alpha$ ) inhibitory effects [81]. However, according to our results, only scopoletin (4) exerted mild inhibition of elastase release. All other isolated compounds including dihydrodehydrodiconiferyl alcohol glycosides ( 6 and 7) were inactive in fMLF-activated human neutrophils.

\section{Conclusions}

The total extract and fractions of $B$. rupestris and B. discolor were nontoxic against hepatoma, breast and lung cancer cell lines. The crude extracts as well as the $n$-hexane and dichloromethane fractions of B. rupestris and $B$. discolor exhibited significant anti-allergic as well as anti-inflammatory activities. The phytochemical study of the leaves of $B$. rupestris resulted in the isolation of compounds from different chemical classes, including triterpene, sterols, sterol glycoside, coumarin and neolignans. All the tested compounds were nontoxic against the tested cancer cell lines. Among the isolated compounds, scopoletin exerted anti-allergic effects and mild anti-inflammatory activity by reducing elastase release in human neutrophils. However, the bioactivity of $B$. rupestris extracts and fractions was much more potent compared with any of the isolated compounds. Thus, leaves of $B$. rupestris and $B$. discolor are worth to be considered for further development and research based on their anti-allergic and anti-inflammatory activities. In vivo evaluation of the anti-allergic and anti-inflammatory activities is highly recommended for the active fractions of both Brachychiton species.

\section{Additional file}

Additional file 1: Supplementary data contains supplementary figures (Figures S1-S6) showing the spectroscopic data of isolated compounds 1-7 from $n$-hexane, dichloromethane and ethyl acetate fractions of $B$. rupestris. (DOCX $2306 \mathrm{~kb}$ )

\section{Abbreviations}

ANOVA: One-way analysis of variance; APT: Attached proton test; B: Brachychiton; BHT: tert-Butyl-1-hydroxytoluene; BDD: Brachychiton discolor leaves dichloromethane fraction; BDE: Brachychiton discolor leaves ethyl acetate fraction; $\mathrm{BDH}$ : Brachychiton discolor leaves $n$-hexane fraction; BDT: Brachychiton discolor leaves total extract; BRD: Brachychiton rupestris leaves dichloromethane fraction; BRE: Brachychiton rupestris leaves ethyl acetate fraction;

$\mathrm{BRH}$ : Brachychiton rupestris leaves $n$-hexane fraction; BRR: $B$. rupestris remaining fraction; BRT: Brachychiton rupestris leaves total extract; $\mathrm{CDCL}_{3}$ : Deuterated chloroform; $\mathrm{CD}_{3} \mathrm{OD}$ : Deuterated methanol; ${ }^{13} \mathrm{C}-\mathrm{NMR}$ : Carbon-13 Nuclear Magnetic Resonance; d: doublet; dd: doublet of doublet; DMEM: Dulbecco's modified Eagle's medium; DMSO: Dimethylsulfoxide; DMSO-d6: Deuterated dimethylsulfoxide-d6; 2D-NMR: Two-dimensional nuclear magnetic resonance spectroscopy; DNP: Dinitrophenyl; DNP-BSA: Dinitrophenyl-conjugated bovine serum albumin; ESI-MS: Electro-Spray Ionization Mass Spectrometry; EtOAc: Ethyl acetate; FBS: Fetal bovine serum; fMLF/CB: formyl-methionyl-leucyl-

phenylalanine/cytochalasin $\mathrm{B} ;{ }^{1} \mathrm{H}-{ }^{1} \mathrm{H}$ COSY: ${ }^{1} \mathrm{H}-{ }^{1} \mathrm{H}$ Correlated spectroscopy; HMBC: Heteronuclear Multiple-Bond Correlation Spectroscopy; ${ }^{1} \mathrm{H}-\mathrm{NMR}$ : Proton Nuclear Magnetic Resonance; HSQC: Heteronuclear Single Quantum Coherence; $\mathrm{IC}_{50}$ : The half maximal inhibitory concentration; $m$ : multiplet; $\mathrm{MTT}$ : (3-(4,5dimethylthiazol-2-yl)-2,5-diphenyltetrazolium bromide); $p$-NAG: $p$-Nitrophenyl-Nacetyl-D-glucosaminide; PTLC: Preparative thin layer chromatography; q: quartet; R. Retardation factor; s: Singlet; S.D.: Standard deviation; SEM: Standard error of mean; $t$ : Triplet; TLC: Thin Layer Chromatography; UPLC: Ultra Performance Liquid Chromatography

\section{Acknowledgements}

We are grateful to the Center for Research Resources and Development, Kaohsiung Medical University for providing instrumentation support and to Ms. Shu-Li Chen for kind assistance in cytotoxicity measurements. Also, we would like to thank the Center for Drug Discovery, Research and

Development at Faculty of Pharmacy, Ain Shams University for the analyses of the isolated compounds.

\section{Funding}

This research was financial supported by the grants from the Ministry of Science and Technology (MOST 107-2911-I-037-502, MOST 106-2320-B037-007-MY3, MOST 106-2320-B-255-003-MY3 and MOST 104-2320-B-255004-MY3), Ministry of Education (EMRPD1G0231), Kaohsiung Medical University (106CM-KMU-02, KMU-DK107003, KMU-M106009), and Chang Gung Memorial Hospital (CMRPF1F0011 3, CMRPF1F0061 3,

CMRPF1G0241 3, and BMRP450), Taiwan. The funders had no role in study design, data collection and analysis, decision to publish, or preparation of the manuscript. 


\section{Availability of data and materials}

The datasets used and/or analysed during the current study are available from the corresponding author on reasonable request.

\section{Authors' contributions}

AAT and FSY performed extraction, isolation and identification of pure compounds and shared writing the whole manuscript. MK, YCW, and BHC carried out the cytotoxic and anti-allergic studies, interpreted the results and edited the manuscript. ME, FRC and ANBS formulated the research hypothesis, supervised the biological part and shared in critical revision of the manuscript and the whole work. TLH contributed to the anti-inflammatory assays. All authors participated in interpretations of results, read and approved the final manuscript.

\section{Ethics approval and consent to participate}

Not applicable.

\section{Consent for publication}

Not applicable.

\section{Competing interests}

The authors declare that they have no competing interests.

\section{Publisher's Note}

Springer Nature remains neutral with regard to jurisdictional claims in published maps and institutional affiliations.

\section{Author details}

'Department of Pharmacognosy, Faculty of Pharmacy, Ain Shams University, African Union Organization Street, Abbassia, Cairo 11566, Egypt. ' ${ }^{2}$ Graduate Institute of Natural Products, College of Pharmacy, Kaohsiung Medical University, Kaohsiung 80708, Taiwan. ${ }^{3}$ Department of Biotechnology, College of Life Science, Kaohsiung Medical University, Kaohsiung 80708, Taiwan. ${ }^{4}$ Graduate Institute of Natural Products, College of Medicine, Chang Gung University, Taoyuan 33302, Taiwan. ${ }^{5}$ Research Center for Chinese Herbal Medicine, Research Center for Food and Cosmetic Safety, and Graduate Institute of Health Industry Technology, College of Human Ecology, Chang Gung University of Science and Technology, Taoyuan 33302, Taiwan. ${ }^{6}$ National Research Institute of Chinese Medicine, Ministry of Health and Welfare, Taipei 11221, Taiwan. ${ }^{7}$ Research Center for Natural Products \& Drug Development, Kaohsiung Medical University, Kaohsiung 80708, Taiwan. ${ }^{8}$ Department of Medical Research, Kaohsiung Medical University Hospital, Kaohsiung 80708, Taiwan. ${ }^{9}$ The Institute of Biomedical Sciences, National Sun Yat-sen University, Kaohsiung 80424, Taiwan. ${ }^{10}$ Department of Pharmaceutical Biology, Faculty of Pharmacy and Biotechnology, German University in Cairo, Cairo 11835, Egypt. ${ }^{11}$ Department of Anesthesiology, Chang Gung Memorial Hospital, Taoyuan 33305, Taiwan. ${ }^{12}$ Chinese Herbal Medicine Research Team, Healthy Aging Research Center, Chang Gung University, Taoyuan 33302, Taiwan. ${ }^{13}$ Department of Chemical Engineering, Ming Chi University of Technology, New Taipei City 24301, Taiwan.

Received: 26 June 2018 Accepted: 24 October 2018

\section{Published online: 09 November 2018}

\section{References}

1. Kawai M, Hirano T, Higa S, Arimitsu J, Maruta M, Kuwahara Y, et al. Flavonoids and related compounds as anti-allergic substances. Allergol Int. 2007:56:113-23.

2. Galli SJ, Tsai M, Piliponsky AM. The development of allergic inflammation. Nature 2008;454:445-454

3. Broide DH. Immunomodulation of allergic disease. Annu Rev Med. 2009;60: 279-91.

4. Baek K-S, Yi Y-S, Son Y-J, Yoo S, Sung NY, Kim Y, et al. In vitro and in vivo anti-inflammatory activities of Korean red ginseng-derived components. J Ginseng Res. 2016:40:437-44.

5. Wang Y-T, Zhu L, Zeng D, Long W, Zhu S-M. Chemical composition and anti-inflammatory activities of essential oil from Trachydium roylei. J Food Drug Anal. 2016;24:602-9.

6. Shaikh RU, Pund MM, Gacche RN. Evaluation of anti-inflammatory activity of selected medicinal plants used in Indian traditional medication system in vitro as well as in vivo. J Tradit Complement Med. 2016;6:355-61.
7. Andhare RN, Raut MK, Naik SR. Evaluation of antiallergic and antianaphylactic activity of ethanolic extract of Sanseveiria trifasciata leaves (EEST) in rodents. J Ethnopharmacol. 2012;142:627-33.

8. Sato A, Zhang T, Yonekura L, Tamura $H$. Antiallergic activities of eleven onions (Allium cepa) were attributed to quercetin 4'-glucoside using QuEChERS method and Pearson's correlation coefficient. J Funct Foods. 2015;14:581-9.

9. Shi Y-H, Zhu S, Ge Y-W, He Y-M, Kazuma K, Wang Z, et al. Monoterpene derivatives with anti-allergic activity from red peony root, the root of Paeonia lactiflora. Fitoterapia. 2016;108:55-61.

10. Singh B, Nadkarni JR, Vishwakarma RA, Bharate SB, Nivsarkar M, Anandjiwala S. The hydroalcoholic extract of Cassia alata (Linn.) leaves and its major compound rhein exhibits antiallergic activity via mast cell stabilization and lipoxygenase inhibition. J Ethnopharmacol. 2012;141:469-73.

11. Tian J, Che H, Ha D, Wei Y, Zheng S. Characterization and anti-allergic effect of a polysaccharide from the flower buds of Lonicera japonica. Carbohydr Polym. 2012;90:1642-7.

12. Silva FV, Oliveira IS, Figueiredo KA, Melo Júnior FB, Costa DA, Chaves MH, et al. Anti-inflammatory and antinociceptive effects of Sterculia striata a. St.-Hil. \& Naudin (Malvaceae) in rodents. J Med Food. 2014:17:694-700.

13. Dai Y, Harinantenaina L, Brodie PJ, Callmander MW, Randrianasolo S, Rakotobe $\mathrm{E}$, et al. Isolation and synthesis of two antiproliferative calamenene-type sesquiterpenoids from Sterculia tavia from the Madagascar rain forest. Bioorg Med Chem. 2012;20:6940-4.

14. Guymer GP. A taxonomic revision of Brachychiton (Sterculiaceae). Aust Syst Bot. 1988:1:199-323.

15. Wilkie P, Clark A, Pennington RT, Cheek M, Bayer C, Wilcock CC. Phylogenetic relationships within the subfamily Sterculioideae (Malvaceae/SterculiaceaeSterculieae) using the chloroplast gene ndhF. Syst Bot. 2006;31:160-70.

16. Salem MZM, Ali HM, Mansour MM. Fatty acid methyl esters from air-dried wood, bark, and leaves of Brachychiton diversifolius R. Br: antibacterial, antifungal, and antioxidant activities. Bioresources. 2014;9:3835-45.

17. Rao KS. Characteristics and fatty acid composition of Brachychiton species seeds and the oils (Sterculiaceae). J Agric Food Chem. 1991;39:881-2.

18. Abdel-Megeed A, Salem MZ, Ali HM, Gohar YM. Brachychiton diversifolius as a source of natural products: antibacterial and antioxidant evaluation of extracts of wood branches. J Pure Appl Microbiol. 2013;7:1843-50.

19. Yousif F, Hifnawy MS, Soliman G, Boulos L, Labib T, Mahmoud S, et al. Large-scale in vitro screening of Egyptian native and cultivated plants for schistosomicidal activity. Pharm Biol. 2007;45:501-10.

20. Thabet AA, Youssef FS, El-Shazly M, El-Beshbishy HA, Singab ANB. Validation of the antihyperglycaemic and hepatoprotective activity of the flavonoid rich fraction of Brachychiton rupestris using in vivo experimental models and molecular modelling. Food Chem Toxicol. 2018;114:302-10.

21. Kassem HA, Eid HH, Abdel-Latif HA. Phytochemical and hypoglycemic studies of the leaves of Brachychiton australis (Schott \& Endl.) a. Terrac. Grown in Egypt. Bull Fac Pharm Cairo Univ. 2001;40:85-91.

22. De Laurentis N, Armenise D, Milillo M, Matrella R. Chemical investigation of Sterculia acerifolia leaves. Riv Ital EPPOS. 2003;13:21-30.

23. Kassem HA. Study of further phytoconstituents of Brachychiton discolor F.J. Muell. cultivated in Egypt. Bull Fac Pharm Cairo Univ. 2007;45:155-60.

24. Kassem HA, Aziz WM. A Pharmacognostical study of Brachychiton discolor F. J.Muell. Cultivated in Egypt. Az Pharm Sci. 2002;29:196-219.

25. Chapman AD. Australian plant name index: Australian Biological Resources Study Canberra; 1991.

26. The International Plant Names Index. 2012. http://www.ipni.org. Accessed 24 Sept 2018.

27. The Plant List. Version 1. 2010. http://www.theplantlist.org. Accessed 24 Sept 2018.

28. Desoky E, Youssef S. Hypoglycaemic effect of Sterculia rupestris and a comparative study of its flavonoids with Sterculia diversifolia. Bull Fac Pharm Cairo Univ. 1997:35:257-61.

29. Okoye NN, Ajaghaku DL, Okeke HN, llodigwe EE, Nworu CS, Okoye FB. BetaAmyrin and alpha-amyrin acetate isolated from the stem bark of Alstonia boonei display profound anti-inflammatory activity. Pharm Biol. 2014;52:1478-86.

30. Oliveira FA, Lima-Junior RCP, Cordeiro WM, Vieira-Júnior GM, Chaves MH, Almeida FRC, et al. Pentacyclic triterpenoids, $a$, $\beta$-amyrins, suppress the scratching behavior in a mouse model of pruritus. Pharmacol Biochem Behav. 2004;78:719-25.

31. Ayeleso TB, Matumba MG, Mukwevho E. Oleanolic acid and its derivatives: biological activities and therapeutic potential in chronic diseases. Molecules. 2017;22:1915 
32. Córdova C, Gutiérrez B, Martínez-García C, Martín R, Gallego-Muñoz P, Hernández $\mathrm{M}$, et al. Oleanolic acid controls allergic and inflammatory responses in experimental allergic conjunctivitis. PLoS One. 2014;9:e91282.

33. Geetha T, Varalakshmi P. Anti-inflammatory activity of lupeol and lupeol linoleate in rats. J Ethnopharmacol. 2001;76:77-80.

34. Khan AS. Antipyretic and analgesic activities of some economically important woody plants. In: Medicinally important trees: Springer; 2017. p. 159-85.

35. Mujumdar AM, Naik DG, Waghole RJ, Kulkarni DK, Kumbhojka MS. Pharmacological studies on Sterculia foetida leaves. Pharm Biol. 2000;38:13-7.

36. Raja T. Evaluation of anticonvulsant effect of Sterculia foetida (Pinari) in pentylenetetrazole (PTZ) and MES induced convulsions in albino rats. World J Pharm Pharm Sci. 2014;3:1898-907.

37. Babalola IT, Adelakun EA, Wang Y, Shode FO. Anti-TB activity of Sterculia setigera Del., leaves (Sterculiaceae). J Pharmacogn. Phytochemistry. 2012;1: 19-26.

38. Tor-Anyiin T, Akpuaka M, Oluma H. Phytochemical and antimicrobial studies on stem bark extract of Sterculia setigera, Del. Afr J Biotechnol. 2011;10: 11011-5.

39. Hossain MM, AlH E, Akbar MA, Ganguly A, Rahman SA. Evaluation of analgesic activity of Sterculia villosa Roxb.(Sterculiaceae) bark in swiss-albino mice. Dhaka Univ J Pharm Sci. 2013;12:125-9.

40. Hossain MF, Talukder B, Rana MN, Tasnim R, Nipun TS, Uddin SN, et al. In vivo sedative activity of methanolic extract of Sterculia villosa Roxb. Leaves. BMC Complement Altern Med. 2016;16:398.

41. Sobeh M, Mamadalieva NZ, Mohamed T, Krstin S, Youssef FS, Ashour ML, et al. Chemical profiling of Phlomis thapsoides (Lamiaceae) and in vitro testing of its biological activities. Med Chem Res. 2016;25:2304-15.

42. Van de Loosdrecht AA, Nennie E, Ossenkoppele GJ, Beelen RH, Langenhuijsen MM. Cell mediated cytotoxicity against U 937 cells by human monocytes and macrophages in a modified colorimetric MTT assay: a methodological study. J Immunol Methods. 1991;141:15-22.

43. Marks DC, Belov L, Davey MW, Davey RA, Kidman AD. The MTT cell viability assay for cytotoxicity testing in multidrug-resistant human leukemic cells. Leuk Res. 1992;16:1165-73.

44. Chen B-H, Wu P-Y, Chen K-M, Fu T-F, Wang H-M, Chen C-Y. Antiallergic potential on RBL-2H3 cells of some phenolic constituents of Zingiber officinale (ginger). J Nat Prod. 2009;72:950-3.

45. Korinek M, Tsai YH, El-Shazly M, Lai KH, Backlund A, Wu SF, et al. Antiallergic hydroxy fatty acids from Typhonium blumei explored through ChemGPS-NP. Front Pharmacol. 2017:8:356.

46. Matsuda H, Tewtrakul S, Morikawa T, Nakamura A, Yoshikawa M. Antiallergic principles from Thai zedoary: structural requirements of curcuminoids for inhibition of degranulation and effect on the release of TNF- $a$ and IL-4 in RBL-2H3 cells. Bioorg Med Chem. 2004;12:5891-8.

47. Chen B-H, Hung M-H, Chen JY-F, Chang H-W, Yu M-L, Wan L, et al. Antiallergic activity of grapeseed extract (GSE) on RBL-2H3 mast cells. Food Chem. 2012;132:968-74.

48. Chung Y-M, Chang F-R, Tseng T-F, Hwang T-L, Chen L-C, Wu S-F, et al. A novel alkaloid, aristopyridinone a and anti-inflammatory phenanthrenes isolated from Aristolochia manshuriensis. Bioorg Med Chem Lett. 2011;21: 1792-4

49. Yang SC, Chung PJ, Ho CM, Kuo CY, Hung MF, Huang YT, et al. Propofol inhibits superoxide production, elastase release, and chemotaxis in formyl peptide-activated human neutrophils by blocking formyl peptide receptor 1. J Immunol. 2013;190:6511-9.

50. Mócsai A, Jakus Z, Tibor Vántus T, Berton G, Lowell GA, Ligeti E. Kinase pathways in chemoattractant-induced degranulation of neutrophils: the role of p38 mitogen-activated protein kinase activated by Src family kinases. J Immunol. 2000;164:4321-31.

51. Liou JR, El-Shazly M, Du YC, Tseng CN, Hwang TL, Chuang YL, et al. 1,5Diphenylpent-3-en-1-ynes and methyl naphthalene carboxylates from Lawsonia inermis and their anti-inflammatory activity. Phytochemistry. 2013; 88:67-73.

52. Youssef FS, Ashour ML, Sobeh M, El-Beshbishy HA, Singab ANB, Wink M. Eremophila maculata- isolation of a rare naturally-occurring lignan glycoside and the hepatoprotective activity of the leaf extract. Phytomedicine. 2016; 23:1484-93.

53. Dubey $\mathrm{H}$, Ticari J. Flavonoids and other constituents of Sterculia genus. J Indian Chem Soc. 1991;68:426-7.

54. Anjaneyulu A, Raju S. Terpenoids and phenolics from the bark and heartwood of Sterculiaurens ROXB. J Indian Chem Soc. 1987;64:323-4.
55. Khan NMU, Hossain MS. Scopoletin and B-sitosterol glucoside from roots of Ipomoea digitata. J Pharmacogn. Phytochemistry. 2015;4:05-7.

56. H-x K, Y-g X, B-y Y, Wang Q-h, S-w L. Lignan constituents from Chloranthus japonicus Sieb. Arch Pharm Res. 2009;32:329-34.

57. Lee S, Song I-H, Lee J-H, Yang W-Y, Oh K-B, Shin J. Sortase a inhibitory metabolites from the roots of Pulsatilla koreana. Bioorg Med Chem Lett. 2014;24:44-8

58. De Souza Santos M, Jonis Andrioli W, Freire de Morais Del Lama MP, Kenupp Bastos J, NPD N, Zumstein Georgetto Naal RM. In vitro anti-allergic activity of the fungal metabolite pyridovericin. Int Immunopharmacol. 2013; 15:532-8.

59. Korinek M, Chen KM, Jiang YH, El-Shazly M, Stocker J, Chou CK, et al. Antiallergic potential of Typhonium blumei: inhibition of degranulation via suppression of PI3K/PLCgamma2 phosphorylation and calcium influx. Phytomedicine. 2016:23:1706-15.

60. Ryu SY, Oak MH, Yoon SK, Cho DI, Yoo GS, Kim TS, et al. Anti-allergic and anti-inflammatory triterpenes from the herb of Prunella vulgaris. Planta Med. 2000;66:358-60.

61. Yoshikawa M, Nakamura S, Kato Y, Matsuhira K, Matsuda H. Medicinal flowers. XIV. New acylated oleanane-type triterpene oligoglycosides with antiallergic activity from flower buds of chinese tea plant (Camellia sinensis). Chem Pharm Bull. 2007:55:598-605.

62. Chen M-L, Hsieh C-C, Chiang B-L, Lin B-F. Triterpenoids and polysaccharide fractions of Ganoderma tsugae exert different effects on antiallergic activities. Evid Based Complement Altern Med. 2015;2015:1-10.

63. Nirmal SA, Patel AP, Bhawar SB, Pattan SR. Antihistaminic and antiallergic actions of extracts of Solanum nigrum berries: possible role in the treatment of asthma. J Ethnopharmacol. 2012;142:91-7.

64. Mahajan SG, Mehta AA. Suppression of ovalbumin-induced Th2-driven airway inflammation by beta-sitosterol in a Guinea pig model of asthma. Eur J Pharmacol. 2011;650:458-64.

65. Bouic $\mathrm{P}$, Lamprecht JH. Plant sterols and sterolins: a review of their immunemodulating properties. Altern Med Rev. 1999;4:170-7.

66. Hwang TL, Yeh SH, Leu YL, Chern CY, Hsu HC. Inhibition of superoxide anion and elastase release in human neutrophils by 3 '-isopropoxychalcone via a CAMP-dependent pathway. Br J Pharmacol. 2006;148:78-87.

67. Mantovani A, Cassatella MA, Costantini C, Jaillon S. Neutrophils in the activation and regulation of innate and adaptive immunity. Nat Rev Immunol. 2011;11:519-31.

68. Kim JA, Son JH, Song SB, Yang SY, Kim YH. Sterols isolated from seeds of Panax ginseng and their antiinflammatory activities. Pharmacogn Mag. 2013;9:182.

69. Kaith BS, Kaith NS, Chauhan NS. Anti-inflammatory effect of Arnebia euchroma root extracts in rats. J Ethnopharmacol. 1996;55:77-80.

70. Vassallo A, De Tommasi N, Merfort I, Sanogo R, Severino L, Pelin M, et al Steroids with anti-inflammatory activity from Vernonia nigritiana Oliv. \& Hiern. Phytochemistry. 2013;96:288-98.

71. Bouic PJ. The role of phytosterols and phytosterolins in immune modulation: a review of the past 10 years. Curr Opin Clin Nutr Metab Care. 2001;4:471-5.

72. Lee J-H, Lee JY, Park JH, Jung HS, Kim JS, Kang SS, et al. Immunoregulatory activity by daucosterol, a $\beta$-sitosterol glycoside, induces protective Th1 immune response against disseminated candidiasis in mice. Vaccine. 2007; 25:3834-40.

73. Correa G, Abreu VDC, Martins D, Takahashi JA, Fontoura H, Cara DC, et al. Antiinflamatory and antimicrobial activities of steroids and triterpenes isolated from aerial parts of Justicia acuminatissima (Acanthaceae). Int J Pharm Pharm Sci. 2014;6:75-81.

74. de Almeida PD, Boleti AP, Rudiger AL, Lourenco GA, da Veiga Junior VF, Lima ES. Anti-inflammatory activity of triterpenes isolated from Protium paniculatum oil-resins. Evid Based Complement Altern Med. 2015;2015:293768.

75. Romero-Estrada A, Maldonado-Magaña A, González-Christen J, Bahena SM, Garduño-Ramírez ML, Rodríguez-López V, et al. Anti-inflammatory and antioxidative effects of six pentacyclic triterpenes isolated from the Mexican copal resin of Bursera copallifera. BMC Complement Altern Med. 2016;16:422.

76. Thirupathi A, Silveira PC, Nesi RT, Pinho RA. Beta-Amyrin, a pentacyclic triterpene, exhibits anti-fibrotic, anti-inflammatory, and anti-apoptotic effects on dimethyl nitrosamine-induced hepatic fibrosis in male rats. Hum Exp Toxicol. 2017:36:113-22.

77. Wei W, Wu X-W, Deng G-G, Yang X-W. Anti-inflammatory coumarins with short- and long-chain hydrophobic groups from roots of Angelica dahurica cv. Hangbaizhi. Phytochemistry. 2016;123:58-68. 
78. Azelmat J, Fiorito S, Taddeo VA, Genovese S, Epifano F, Grenier D. Synthesis and evaluation of antibacterial and anti-inflammatory properties of naturally occurring coumarins. Phytochem Lett. 2015;13:399-405.

79. Kang K-H, Kong C-S, Seo Y, Kim M-M, Kim S-K. Anti-inflammatory effect of coumarins isolated from Corydalis heterocarpa in $\mathrm{HT}-29$ human colon carcinoma cells. Food Chem Toxicol. 2009;47:2129-34.

80. Shih H-C, Kuo P-C, Wu S-J, Hwang T-L, Hung H-Y, Shen D-Y, et al. Antiinflammatory neolignans from the roots of Magnolia officinalis. Bioorg Med Chem. 2016;24:1439-45.

81. Peng Y, Lou L-L, Liu S-F, Zhou L, Huang X-X, Song S-J. Antioxidant and antiinflammatory neolignans from the seeds of hawthorn. Bioorg Med Chem Lett. 2016;26:5501-6.

Ready to submit your research? Choose BMC and benefit from:

- fast, convenient online submission

- thorough peer review by experienced researchers in your field

- rapid publication on acceptance

- support for research data, including large and complex data types

- gold Open Access which fosters wider collaboration and increased citations

- maximum visibility for your research: over $100 \mathrm{M}$ website views per year

At BMC, research is always in progress.

Learn more biomedcentral.com/submissions 